\title{
Flies with Parkinson's disease
}

\author{
Roeland Vanhauwaert ${ }^{\mathrm{a}, \mathrm{b}}$, Patrik Verstreken ${ }^{\mathrm{a}, \mathrm{b}, *}$ \\ a VIB Center for the Biology of Disease, KU Leuven, Herestraat 49,3000 Leuven, Belgium \\ b Laboratory of Neuronal Communication, Leuven Institute for Neurodegenerative Disease (LIND), Center for Human Genetics, KU Leuven, Herestraat 49 , 3000 Leuven, Belgium
}

\section{A R T I C L E I N F O}

Article history:

Received 25 December 2014

Accepted 11 February 2015

Available online $\mathrm{xxxx}$

\begin{abstract}
Parkinson's disease is an incurable neurodegenerative disease. Most cases of the disease are of sporadic origin, but about $10 \%$ of the cases are familial. The genes thus far identified in Parkinson's disease are well conserved. Drosophila is ideally suited to study the molecular neuronal cell biology of these genes and the pathogenic mutations in Parkinson's disease. Flies reproduce quickly, and their elaborate genetic tools in combination with their small size allow researchers to analyze identified cells and neurons in large numbers of animals. Furthermore, fruit flies recapitulate many of the cellular and molecular defects also seen in patients, and these defects often result in clear locomotor and behavioral phenotypes, facilitating genetic modifier screens. Hence, Drosophila has played a prominent role in Parkinson's disease research and has provided invaluable insight into the molecular mechanisms of this disease.
\end{abstract}

A B S T R A C T

\section{Introduction}

Parkinson's disease (PD) is the most common neurodegenerative movement disorder. Several million people in the world suffer from this disease and the estimated prevalence ranges from $0.01 \%$ to $1.2 \%$ of the world population. Age is the most common risk factor for PD and given that the population ages, the incidence of this disease is predicted to double by 2040 (Gustavsson et al., 2011; Kowal et al., 2013; von Campenhausen et al., 2005). Several symptomatic treatments for PD exist, but their effect is limited in time as the disease relentlessly progresses (Athauda and Foltynie, 2014; Ossig and Reichmann, 2015). Hence, a better understanding of the underlying pathology is needed to arrive at more powerful disease modifying strategies.

One of the best recognized pathological hallmarks of PD is the loss of dopaminergic neurons in the substantia nigra (Hirsch et al., 1988; Schneider and Obeso, 2014). Much of the research has therefore focused on strategies to protect these neurons from dying. Both pharmacological strategies (e.g. MPTP treatment (Blandini and Armentero, 2012; Bové and Perier, 2012)), as well as genetic strategies (e.g. POLG mutations (Dai et al., 2014; Humphrey et al., 2012; Orsucci et al., 2011)), have been exploited to kill dopaminergic neurons in model organisms, but it is questionable if the molecular mechanisms that are affected by these treatments overlap with those that are defective in PD. In fact, many of genes that are causative to PD (see below) are very broadly expressed also outside of dopaminergic neurons (d'Amora et al., 2011; Kühn et al., 2004; Mandemakers et al., 2012; Wirdefeldt and Bogdanovic, 2001). In humans, mutations in these broadly expressed genes lead to the loss of dopaminergic neurons in the brain, but the function of several other types of cells is likely compromised as well (Davie, 2008; Shulman et al., 2011). Hence, studying cellular defects caused by PD, also outside the dopaminergic system, may yield valuable insight into the molecular mechanisms that are at the basis of PD as well. It seems then that eventually, the dopaminergic neurons appear particularly vulnerable to defects in these pathways-the reasons for this are enigmatic-.

Most of the PD cases are of sporadic origin where environmental or genetic factors contribute to the development of the disease. About 10\% of the cases are familial and single gene mutations are causative to the disease. Much of the research in PD has focused on these familial forms. To date 20 PD susceptibility loci have been identified, and for about half, the causative gene has been isolated (Table 1). Most of the genes involved in PD are evolutionary conserved, and they can be readily modeled in genetic model organisms, such as fruit flies, where the consequence of their loss- or gain-of-function can be studied and where genetic and pharmacological modulation of the phenotypes can be assessed. Interestingly, numerous connections between sporadic and familial forms of the disease exist: eg causative genes to PD are misregulated in sporadic forms of the disease (e.g. Parkin or LRRK2 (Chai and Lim, 2013; Lesage and Brice, 2012)), or typical protein aggregates that are often seen in sporadic and familial cases of the disease (Lewy bodies) are enriched in alpha-synuclein, a protein that is also found mutated in some familial forms (Spillantini et al., 1997). 
Table 1

Monogenetic forms of PD and its fly homolog(s). AD, autosomal dominant; AR, autosomal recessive. Adapted from Marras et al. (2012).

\begin{tabular}{|c|c|c|c|c|c|c|}
\hline Symbol & Gene locus & Gene & $\begin{array}{l}\text { Drosophila } \\
\text { homolog }\end{array}$ & Inheritance & Disorder & Status and remarks \\
\hline PARK1 & $4 q 21-22$ & $\begin{array}{l}\text { SNCA (Polymeropoulos } \\
\text { et al., 1997) }\end{array}$ & no homolog & $\mathrm{AD}$ & Early-onset parkinsonism & Confirmed \\
\hline PARK2 & $6 q 25.2-q 27$ & $\begin{array}{l}\text { PARK2 encoding Parkin } \\
\text { (Kitada et al., 1998) }\end{array}$ & parkin & AR & Early onset parkinsonism & Confirmed \\
\hline PARK3 & $2 \mathrm{p} 13$ & Unknown & - & $\mathrm{AD}$ & Classical parkinsonism & Unconfirmed \\
\hline PARK4 & $4 q 21-q 23$ & SNCA & no homolog & $\mathrm{AD}$ & Early-onset parkinsonism & Erroneous locus (identical to PARK1) \\
\hline PARK5 & $4 \mathrm{p} 13$ & UCHL1 & Uch & $\mathrm{AD}$ & Classical parkinsonism & Unconfirmed \\
\hline PARK6 & $1 \mathrm{p} 35-\mathrm{p} 36$ & $\begin{array}{l}\text { PINK1 (Valente } \\
\text { et al., 2004) }\end{array}$ & pink1 & AR & Early onset parkinsonism & Confirmed \\
\hline PARK7 & $1 \mathrm{p} 36$ & $\begin{array}{l}\text { PARK7 encoding DJ-1 } \\
\text { (Bonifati et al., 2003) }\end{array}$ & $D j-1 \alpha$ and $d j-1 \beta$ & AR & Early onset parkinsonism & Confirmed \\
\hline PARK8 & $12 \mathrm{q} 12$ & $\begin{array}{l}\text { LRRK2 (Paisán-Ruíz } \\
\text { et al., 2004) }\end{array}$ & Lrrk & $\mathrm{AD}$ & Classical parkinsonism & Confirmed \\
\hline PARK9 & $1 \mathrm{p} 36$ & $\begin{array}{l}\text { ATP13A2 } \\
\text { (Ramirez et al., 2006) }\end{array}$ & CG32000 & AR & $\begin{array}{l}\text { Kufor-Rakeb syndrome, a form } \\
\text { of juvenile-onset atypical parkinsonism } \\
\text { with dementia, spasticity and supranuclear } \\
\text { gaze palsy }\end{array}$ & Confirmed \\
\hline PARK10 & $1 \mathrm{p} 32$ & Unknown & - & Risk factor & Classical parkinsonism & Confirmed susceptibility locus \\
\hline PARK11 & $2 q 36-27$ & $\begin{array}{l}\text { Unknown } \\
\text { (maybe GIGYF2) }\end{array}$ & - & $\mathrm{AD}$ & Late onset parkinsonism & Not independently confirmed \\
\hline PARK12 & Xq21-q25 & Unknown & - & Risk factor & Classical parkinsonism & Confirmed susceptibility locus \\
\hline PARK13 & 2p12 & HTRA2 & HtrA2 & $\mathrm{AD}$ or risk factor & Classical parkinsonism & Unconfirmed \\
\hline PARK14 & 22q13.1 & $\begin{array}{l}\text { PLA2G6 (Paisan-Ruiz } \\
\text { et al., 2009) }\end{array}$ & iPLA2-VIA & AR & Early-onset dystonia-parkinsonism & Confirmed \\
\hline PARK15 & 22q12-q13 & $\begin{array}{l}\text { FBX07 (Shojaee } \\
\text { et al., 2008) }\end{array}$ & no homolog & AR & Early-onset parkinsonian-pyramidal syndrome & Confirmed \\
\hline PARK16 & $1 q 32$ & $\begin{array}{l}\text { Unknown } \\
\text { (maybe RAB7L1) }\end{array}$ & - & Risk factor & Classical parkinsonism & Confirmed susceptibility locus \\
\hline PARK17 & $16 q 11.2$ & VPS35 & Vps35 & $\mathrm{AD}$ & Classical parkinsonism & Unconfirmed \\
\hline PARK18 & $6 \mathrm{p} 21.3$ & EIF4G1 & eIF4G & $\mathrm{AD}$ & Late onset parkinsonism & Unconfirmed \\
\hline PARK19 & $1 \mathrm{p} 31.3$ & $\begin{array}{l}\text { DNAJC6 (Edvardson } \\
\text { et al., 2012) }\end{array}$ & auxillin & AR & Juvenile-onset parkinsonism & Confirmed \\
\hline PARK20 & 21q22.11 & $\begin{array}{l}\text { SYNJ1 (Krebs et al., 2013; } \\
\text { Quadri et al., 2013) }\end{array}$ & Synj & AR & Early-onset parkinsonism & Confirmed \\
\hline
\end{tabular}

Hence, it is believed that by understanding familial PD, we will also gain insight into the sporadic forms of the disease.

\section{PD modelling in flies}

Ideal murine models for PD do not exist and this gap has maximally allowed Drosophila to step in as an important genetic model in the study of strategies to combat PD. While the fruit fly models also have limitations, they are small and propagate fast, allowing researchers to conduct elaborate genetic screens for modifier loci (see below); yet flies also harbour a complex nervous system with several dopaminergic neuron clusters and they are amenable to live imaging, enabling in vivo cell biological studies (Bier, 2005; White et al., 2010). It is likely that the neuronal connections relevant to PD in humans are likely not highly conserved in the fly brain. However, the combination of fast and elaborate genetics with in depth cell biological and molecular studies does provide a rather unique window on the mechanisms and pathways underlying PD pathogenesis in vivo.

The genes implicated in PD are highly conserved, and for the 14 PD genes currently identified, 12 have a fly homolog (Table 1 ). The two genes that are not conserved are alpha-synuclein (SNCA) and FBXO7 and although these genes are not present in the fly genome, the human versions of these genes with or without pathogenic mutations have been overexpressed in fruit fly neurons allowing researchers to evaluate the defects that are induced and the pathways that are activated (Table 2). Such an approach may be particularly interesting for SNCA where 'gain of protein levels', caused by triplications in humans, have been shown to cause PD as well (Singleton et al., 2003). Overexpression models such as the SNCA models in flies are ideal to conduct biochemical and genetic screens, and this approach has been followed in Drosophila as well as in other model organisms. For example TRAP1 was identified in such a screen (Butler et al., 2012). TRAP1 is a mitochondrial chaperone that already had been implicated to be phosphorylated by another PD-protein Pink1 (Costa et al., 2013; Pridgeon et al., 2007; Zhang et al., 2013). Hence, such interaction screens start to elucidate common pathways that span several of the PD-relevant genes.

Similar to overexpression models, genetic analyses of almost all other PD-relevant genes has been undertaken in fruit flies. Loss-offunction models based on small gene deletions, transposon insertions or chemically induced mutations to almost all PD-relevant genes have been created. Likewise, (over)expression of wild type Drosophila or human versions of the genes or overexpression of pathogenic or enzymatically impaired variants have been generated. Table 2 shows an overview of the extended set of mutations and other genetic tools that have been created to date to study familial PD in flies as well as antibodies or other strategies used to localize the gene products. Fig. 1 shows the timeline of identification of PD genes versus the characterization of the corresponding fly model.

Studies of PD gene function in flies often make use of UAS-Gal4 driven overexpression of pathogenic mutations (Brand and Perrimon, 1993). Such an approach is in several instances probably warranted, but care needs to be taken as to not misinterpret overexpression artifacts, such as the induction of pathways that are normally not being activated (Liu and Lehmann, 2008). The advent of new genome editing strategies based on CRISPR/Cas9 (Bassett et al., 2013; Gratz et al., 2013; Ren et al., 2014) or TALENs (J. Liu et al., 2012; Liu et al., 2014) but also on targeted single strand annealing using MiMIC transposons, is now allowing to very efficiently and locally manipulate the fly genome as to insert tags or pathogenic mutations in PD-relevant genes (Venken et al., 2011; Vilain et al., 2014). These modified genes 
Table 2

Fly PD models and tools.

\begin{tabular}{|c|c|c|c|c|c|c|}
\hline Symbol & Gene & $\begin{array}{l}\text { Drosophila } \\
\text { homolog }\end{array}$ & Loss-of-function mutant & (Over)expression construct & $\begin{array}{l}\text { (Over)expression construct with point } \\
\text { mutation }\end{array}$ & $\begin{array}{l}\text { Drosophila Antibody } \\
\text { or tagged knock-in } \\
\text { allele }\end{array}$ \\
\hline PARK1 & SNCA & $\begin{array}{l}\text { no } \\
\text { homolog }\end{array}$ & - & $\begin{array}{l}\text { Yes (Chen and Feany, 2005; Chen et al., } \\
\text { 2009; Feany and Bender, 2000; Karpinar } \\
\text { et al., 2009; Kontopoulos et al., 2006; } \\
\text { Trinh et al., 2008) }\end{array}$ & $\begin{array}{l}\text { Yes (A30P*-A53T* (Feany and Bender, } \\
\text { 2000), A30P*-A53T* (Karpinar et al., 2009) }\end{array}$ & - \\
\hline PARK2 & $\begin{array}{l}\text { PARK2 } \\
\text { encoding } \\
\text { Parkin }\end{array}$ & parkin & $\begin{array}{l}\text { Yes (Greene et al., 2003; } \\
\text { Pesah et al., 2004; } \\
\text { Whitworth et al., 2005) }\end{array}$ & $\begin{array}{l}\text { Yes (Cha et al., 2005; Greene et al., 2003; } \\
\text { Haywood and Staveley, 2004; } \\
\text { Muñoz-Soriano and Paricio, 2007; Pesah } \\
\text { et al., 2004) (also genomic construct } \\
\text { (Pesah et al., 2004)) }\end{array}$ & $\begin{array}{l}\text { Yes (R42P* (Cha et al., 2005), R275W*, } \\
\text { G328E*(Wang et al., 2007), T187A } \\
\text { (Kim et al., 2008)) }\end{array}$ & Yes (Yang et al., 2006) \\
\hline PARK5 & UCHL1 & Uch & No & No & No & $\begin{array}{l}\text { Yes (Thao et al., 2012; } \\
\text { Tram et al., 2013) }\end{array}$ \\
\hline PARK6 & PINK1 & Pink1 & $\begin{array}{l}\text { Yes (Clark et al., 2006; Park } \\
\text { et al., 2006) }\end{array}$ & $\begin{array}{l}\text { Yes (Clark et al., 2006; Kim et al., 2008; } \\
\text { Park et al., 2006; Todd and Staveley, } \\
\text { 2008; Yang et al., 2006) }\end{array}$ & $\begin{array}{l}\text { Yes (G309D* (Wang et al., 2006), G426D* } \\
\text { (genomic construct) (Yun et al., 2008), } \\
\text { G426D*-L464P* (Song et al., 2013) }\end{array}$ & $\begin{array}{l}\text { Yes (Park et al., 2006; } \\
\text { Yang et al., 2006) }\end{array}$ \\
\hline PARK7 & $\begin{array}{l}\text { PARK7 } \\
\text { encoding } \\
\text { DJ-1 }\end{array}$ & $\begin{array}{l}D j-1 \alpha \text { and } \\
d j-1 \beta\end{array}$ & $\begin{array}{l}\text { Yes (Lavara-Culebras and } \\
\text { Paricio, 2007; Menzies } \\
\text { et al., 2005; Meulener } \\
\text { et al., 2005; Park et al., } \\
\text { 2005) }\end{array}$ & $\begin{array}{l}\text { Yes (Kim et al., 2005; Menzies et al., } \\
\text { 2005; Meulener et al., 2005; Yang et al., } \\
\text { 2005) }\end{array}$ & No & No \\
\hline PARK8 & LRRK2 & Lrrk & $\begin{array}{l}\text { Yes (Lee et al., 2007; Wang } \\
\text { et al., 2008) }\end{array}$ & $\begin{array}{l}\text { Yes (Dodson et al., 2012; Gehrke et al., } \\
\text { 2010; Imai et al., 2008; Lee et al., 2007; } \\
\text { Lin et al., 2010; Martin et al., 2014; } \\
\text { Matta et al., 2012; Ng et al., 2009; } \\
\text { Venderova et al., 2009) (also genomic } \\
\text { construct (Dodson et al., 2012)) }\end{array}$ & $\begin{array}{l}\text { Yes (R1069G*-Y1383C*-I1915T* (Imai et al., } \\
\text { 2008), I1122V*-Y1699C*-I2020T* } \\
\text { (Venderova et al., 2009), } \\
\text { Y1699C*-G2019S*-G2385R* } \\
\text { (Ng et al., } \\
\text { 2009),G2019S*-R1441C*-G2385R* (Lin } \\
\text { et al., 2010), R1069G* (Gehrke et al., 2010), } \\
\text { G1914S* (Dodson et al., 2012), G2019S* } \\
\text { (Matta et al., 2012), G2019S* } \\
\text { (Martin et al., 2014)) }\end{array}$ & $\begin{array}{l}\text { Yes (Imai et al., } \\
\text { 2008) or use tagged } \\
\text { knock-in allele } \\
\text { (LRRK-HA) (Vilain } \\
\text { et al., 2014) }\end{array}$ \\
\hline PARK9 & ATP13A2 & CG32000 & No & Yes (Schertel et al., 2013) & No & No \\
\hline PARK13 & HTRA2 & HtrA2 & $\begin{array}{l}\text { Yes (Tain et al., 2009; } \\
\text { Yacobi-Sharon et al., 2013; } \\
\text { Yun et al., 2008) }\end{array}$ & $\begin{array}{l}\text { Yes (Igaki et al., 2007; Park et al., 2006; } \\
\text { Tain et al., 2009; Whitworth et al., 2008; } \\
\text { Yacobi-Sharon et al., 2013; Yun et al., } \\
\text { 2008) (also genomic construct } \\
\text { (Tain et al., 2009; Yacobi-Sharon } \\
\text { et al., 2013)) }\end{array}$ & $\begin{array}{l}\text { Yes (S236C-S266A-G363S*-S364A* } \\
\text { (Yun et al., 2008) S266A (genomic construct) } \\
\text { (Yacobi-Sharon et al., 2013)) }\end{array}$ & $\begin{array}{l}\text { Yes (Igaki et al., 2007; } \\
\text { Khan et al., 2008) }\end{array}$ \\
\hline PARK14 & PLA2G6 & iPLA2-VIA & Yes (Malhotra et al., 2009) & No & No & No \\
\hline PARK15 & FBXO7 & $\begin{array}{l}\text { no } \\
\text { homolog }\end{array}$ & - & Yes (Burchell et al., 2013) & $\begin{array}{l}\text { Yes (T22M*-R378G*-R498X* (Burchell } \\
\text { et al., 2013)) }\end{array}$ & - \\
\hline PARK17 & VPS35 & Vps35 & $\begin{array}{l}\text { Yes (Belenkaya et al., 2008; } \\
\text { Franch-Marro et al., 2008; } \\
\text { Korolchuk et al., 2007; Port } \\
\text { et al., 2008) }\end{array}$ & $\begin{array}{l}\text { Yes (Belenkaya et al., 2008; S. Wang } \\
\text { et al., 2014) }\end{array}$ & $\begin{array}{l}\text { Yes (P316S*-D620N*-L774M* (H.-S. Wang } \\
\text { et al., 2014)) }\end{array}$ & No \\
\hline PARK18 & EIF4G1 & eIF4G & No & No & No & $\begin{array}{l}\text { Yes (Zapata } \\
\text { et al., 1994) }\end{array}$ \\
\hline PARK19 & DNAJC6 & auxillin & $\begin{array}{l}\text { Yes (Eun et al., 2007; } \\
\text { Hagedorn et al., 2006; } \\
\text { Kandachar et al., 2008) }\end{array}$ & $\begin{array}{l}\text { Yes (Eun et al., 2008; Hagedorn et al., } \\
\text { 2006; Kandachar et al., 2008) (also } \\
\text { genomic construct (Eun et al., 2007)) }\end{array}$ & No & Yes (Eun et al., 2008) \\
\hline PARK20 & SYNJ1 & Synj & $\begin{array}{l}\text { Yes (Muñoz-Soriano and } \\
\text { Paricio, 2007; Verstreken } \\
\text { et al., 2003) }\end{array}$ & $\begin{array}{l}\text { Yes (Dickman et al., 2006) (also genomic } \\
\text { construct (Venken et al., 2008)) }\end{array}$ & No & $\begin{array}{l}\text { Yes (Verstreken } \\
\text { et al., 2003) }\end{array}$ \\
\hline
\end{tabular}

\footnotetext{
* (Over)expression construct with PD-associated mutation.
}

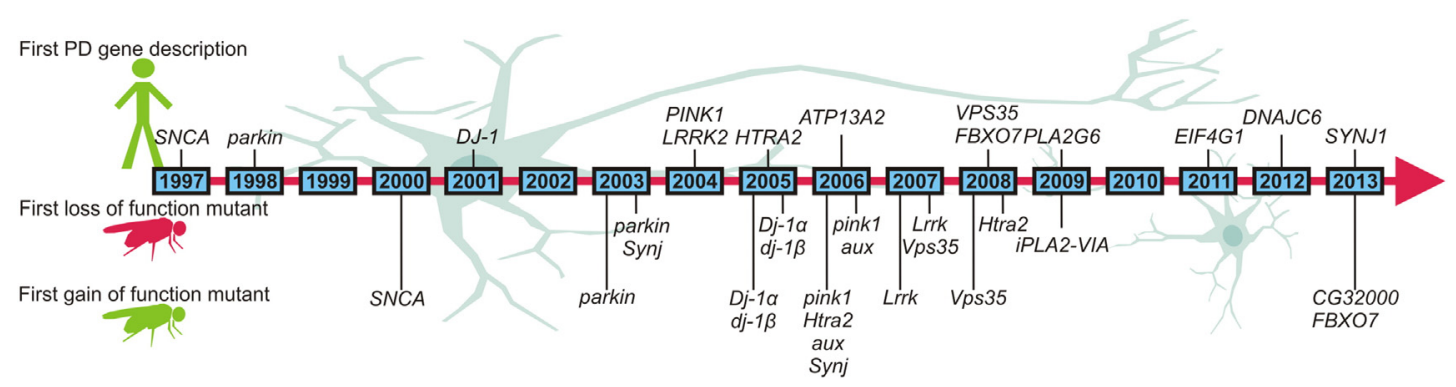

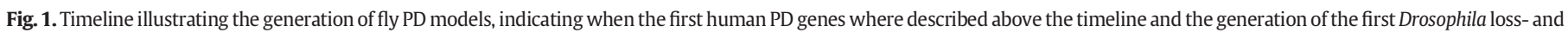
gain-of-function mutant below the timeline. 
are now expressed at endogenous levels. Such technology was already used to tag the endogenous fly $L R R K$ gene with HA for endogenous protein localization (Vilain et al., 2014) and such approaches will become more and more mainstream as they more closely mimic gene dosage in patients.

Flies are well-suited for "in vivo" cell biological studies related to pathogenic pathways in PD because such studies can be readily combined with functional in vivo studies and many genetically identical animals can be analyzed. For example, mitochondrial activity in thoracic and larval muscle cells can be effectively assessed using fluorescent and biochemical assays and the defects observed can be paired with motor defects such as negative geotaxis or the ability of the flies to fly (Ali et al., 2011). Similarly, it is possible to use cell type specific expression of transgenes to assess neuronal cell biology in combination with electrophysiology and electron microscopy at neuromuscular junctions or with confocal imaging in dopaminergic neurons in the fly brain (Brand and Perrimon, 1993; Cao et al., 2013; Engel, 2008; Ramachandran and Budnik, 2010; White et al., 2010; Zhang and Stewart, 2010). Flies can also be aged and the defects that are observed in PD models can be assessed over time. Flies live a relatively short life ( $<80$ days) which facilitates analyses of nervous system phenotypes across the complete lifespan. An important drawback here is that this time frame may be too short for dysfunctional proteins or protein aggregates to accumulate, thus not recapitulating this aspect of pathology. Nonetheless, the expanded repertoire of functional and cell biological assays in combination with the powerful genetic toolbox is exceptional, providing a unique inroad into studying the mechanisms of PD.

\section{Pathways in PD}

Familial PD is caused by mutations in different loci, and the identification of the genes is not revealing one specific pathway that is affected. Similarly, the sporadic factors that are causative to the disease may be diverse as well. It is therefore critical to study the different genetic causes of PD as to assess overlap in pathways but also the differences. Such studies will not only help to identify more effective treatment options but they will also aid in stratifying the PD patient population.

\section{Misregulation of microRNAs}

One of the pathways that is emerging in PD is misregulation of microRNAs (miRNA) and work in fruit flies suggests LRRK2 may be a central player in this process. Fly LRRK binds to Argonaute-1, a central component of the RNA-induced silencing complex (RISC). Further work has shown that pathogenic LRRK2 inhibits let-7 (a miRNA) and miR-184 and this results in the upregulation of two transcription factors E2F1 and DP; a defect connected to locomotor activity defects in flies (Gehrke et al., 2010). Interestingly, the expression of SNCA mRNA is negatively regulated by at least two microRNAs, miR-7 and miR-153 (Doxakis, 2010; Junn et al., 2009) and DJ1 and Parkin expression has also been suggested to be connected to reduced $\mathrm{miR}-34 \mathrm{~b} / \mathrm{c}$ expression in late stage PD brain samples (Miñones-Moyano et al., 2011). While much more work is needed to elucidate which and how miRNAs are controlling PD-gene expression, the discovery that LRRK2 may more directly affect the expression and function of miRNAs themselves may suggest a more direct connection between PD and miRNA function (Ma et al., 2013; Mouradian, 2012).

\section{Vesicle trafficking defects}

Misregulation of the expression of PD genes may have profound effects on cellular and neuronal function and work in flies has provided important insight into these mechanisms. In recent years a role for vesicle trafficking has emerged and several of the genes involved in PD have been suggested to play an active role in the process. Alpha- synuclein, LRRK2, Vps35, Synaptojanin, Parkin and DNAJC6/auxillin are directly connected to the process and several of these proteins have been extensively studied in fruit flies (Dodson et al., 2014; Korolchuk et al., 2007; Linhart et al., 2014; MacLeod et al., 2013). Interestingly, work in Drosophila is also helping to start elucidating the connections between these different players; e.g. between SNCA and Vps35 (Miura et al., 2014) or between LRRK2 and Synaptojanin (Matta et al., 2012; Verstreken et al., 2003). Indeed, fly and human LRRK2 can phosphorylate one of the central players in synaptic vesicle endocytosis: Endophilin A, and Endophilin A very tightly binds to Synaptojanin (Ringstad et al., 1997; Verstreken et al., 2002, 2003). Phosphorylation of Endophilin A affects its membrane binding and membrane remodeling properties affecting synaptic vesicle recycling (Ambroso et al., 2014; Matta et al., 2012). While fly Endophilin A is phosphorylated at Serine75, a residue central in the regulation of Endophilin A-membrane interactions, mammalian Endophilin A was recently shown to be phosphorylated at Serine 75 and at Threonine 73 that are located very closely to one another (Arranz et al., 2014; Matta et al., 2012). It is in this context interesting to note that Endophilin A is also ubiquitinated by Parkin and Parkin levels are strongly upregulated in endophilin A mutant mice (Cao et al., 2014; Trempe et al., 2009). Hence, discoveries in Drosophila are adding to the network that is emerging around Endophilin A, but how the function of Endophilin $A$ is connected to the pathogenesis in $P D$ remains to be elucidated.

Providing additional links between PD and synaptic endocytosis, work in flies, mice, nematodes and zebrafish indicate the central role of Synaptojanin in synaptic vesicle uncoating following new vesicle formation (Cremona et al., 1999; Harris et al., 2000; Van Epps et al., 2004; Verstreken et al., 2003). Synaptojanin is a phosphoinositide phosphatase involved in the dephosphorylation of $\mathrm{PI}(4,5) \mathrm{P}_{2}$ (Guo et al., 1999; McPherson et al., 1996), a lipid required for endocytosis (Jost et al., 1998; Koch and Holt, 2012). The work indicates that the absence of Synaptojanin function results in strong defects in the reformation of a synaptic vesicle pool following stimulation because of defects in protein uncoating from nascent synaptic vesicles. Interestingly, DNAJC6/auxillin has been implicated in exactly this same process as well (Ahle and Ungewickell, 1990; Hirst et al., 2008; Scheele et al., 2001; Ungewickell et al., 1995; Yim et al., 2010), suggesting that this function is somehow connected to PD-relevant pathways. However, the links between synaptic vesicle uncoating and neurodegeneration are yet to be elucidated.

These findings in fruit flies, but also the work in many other systems strongly implicate a group of PD-relevant proteins rather directly in (synaptic) vesicle trafficking steps (Braschi et al., 2010; Cirnaru et al., 2014; Gitler et al., 2008; McLean et al., 2000; Piccoli et al., 2011; Soper et al., 2011; Vargas et al., 2014; Yun et al., 2013). This work then opens the question as to how defects in vesicle trafficking can be connected to PD? Vesicle trafficking is closely connected to autophagy where pre-autophagic membrane vesicles fuse to create autophagosomes that engulf debris and destine it for degradation (Ge et al., 2014; Yamamoto et al., 2012). It is conceivable that defects in this turnover pathway may result in cellular stress as a result of defects in protein turn over. However, how defects in autophagy cause cellular dysfunction in specific cell types remains to be elucidated. Vesicle trafficking defects may also cause altered localization of membrane bound receptors thus affecting signaling pathways. At the synapse, defects in vesicle recycling will also lead to defects in neurotransmitter release, thus causing altered information transfer in neuronal circuits. In dopaminergic neurons, slower vesicle recycling would in theory result in less dopamine uptake into synaptic vesicles and increased cytoplasmic dopamine levels. Dopamine is toxic and creates reactive oxygen species (ROS) (Lotharius and O'Malley, 2000) and removing it from the cytoplasm may be protective. In line with this idea, over expression of the vesicular dopamine transporter is protective in PD-fly models (Lawal et al., 2010). Hence, several models that connect defects in vesicle trafficking to cellular survival are 
emerging (Esposito et al., 2012), but additional work is needed to link this process to pathology.

\section{Mitochondrial dysfunction}

While vesicle trafficking defects in PD are emerging in recent years, mitochondrial dysfunction in the disease is recognized since long and both sporadic and genetic forms of the disease have been connected to these organelles. Post mortem brain samples from PD patients often show mitochondrial defects (Arthur et al., 2009; Keeney et al., 2006; Naydenov et al., 2010), and pesticides or mitochondrial toxins have been connected to PD-like symptoms in humans and laboratory animals (Betarbet et al., 2000; Blandini and Armentero, 2012; Bové and Perier, 2012; Langston et al., 1983). In addition, several of the PD-proteins have also been shown to affect mitochondria, including DJ-1, Pink1 and Parkin. Interestingly, PD-causing mutations in all these genes are recessive and loss-of-function animals are thus good systems to model these types of PD. Also here, fruit fly research has made important contributions. For example DJ-1 mutant Drosophila show compromised mitochondrial function with age (Hao et al., 2010), and these defects are also seen in DJ-1 mutant mice (Irrcher et al., 2010). Interestingly, also pink1 and parkin mutant flies show mitochondrial defects that overlap with the defects seen in the DJ-1 mutants (Hao et al., 2010). Further work is now needed to connect the role of DJ-1 to the functions of Pink1 and Parkin in the regulation of mitochondrial function. Furthermore, insight into how such mitochondrial defects would then lead to neuronal loss, in particular dopaminergic neuron loss is also awaited.

One of the significant contributions fruit fly research has made to our understanding of PD relevant pathways was the discovery of mitochondrial defects in genetic models of familial cases of PD. Parkin mutant flies, but also pink1 mutant flies show abnormally positioned wings, dented thoraces and locomotor defects (Clark et al., 2006; Greene et al., 2003; Haywood and Staveley, 2004; Park et al., 2006; Pesah et al., 2004; Yang et al., 2006). Examination of the flight muscles showed disorganized muscle fibers with enlarged mitochondria, explaining the thoracic defects. Although the mitochondrial defects in parkin or pink1 mutants are most obvious in muscle cells that are energy demanding, other cell types, including the dopaminergic neurons in the fly brain, also appear to suffer from mitochondrial defects, suggesting loss of these genes results in systemic mitochondrial defects, but not all tissues suffer to a similar extend (Clark et al., 2006; Greene et al., 2003; Haywood and Staveley, 2004; Park et al., 2006; Pesah et al., 2004; Yang et al., 2006). These early discoveries have then paved the way to much more elaborate investigations that have really gone to the core of the mitochondrial defects. In parallel, addressing these fundamental questions has also provided many exciting avenues in potential therapeutic strategies that are now waiting to be translated.

The similarity between the phenotypes in parkin and pink1 mutant fruit flies is very striking, and also in humans, PD-patients suffering from mutations in the orthologous genes show very similar early onset and slow disease progression phenotypes (Lohmann et al., 2003). These strong overlaps in phenotypes suggested that these genes may act, at least in part, together to protect mitochondria from being damaged. This idea was first tested in fruit flies by showing that expression of wild type Parkin in a pink1 mutant partially alleviates the pink1-associated phenotypes. Conversely, expression of Pink1 in a parkin mutant does not rescue parkin-associated phenotypes, suggesting that Parkin acts in this role downstream of Pink1 (Clark et al., 2006; Park et al., 2006). These observations are interesting in light of an emerging idea that Parkin is needed to the degradation of sick mitochondria by autophagy (mitophagy) and proteasomal degradation of mitochondrial components (Kawajiri et al., 2010; Narendra et al., 2009; Vincow et al., 2013; Yamamoto et al., 2005).

While many questions still remain, work in flies has helped to elucidate important aspects of this mitochondrial quality control pathway. Mitochondria undergo constant fusion and fission, and it is believed that this process is needed to exchange mitochondrial material and maintain a healthy mitochondrial pool. It is also thought that mitochondrial fission precedes mitochondrial autophagy as to separate the dysfunctional mitochondrial pieces from the healthy ones. In line with this idea, early work in flies indicated that increased fission or decreased fusion restores many of the mitochondrial morphological defects seen in pink1 and parkin mutants (Deng et al., 2008; Poole et al., 2008; Yang et al., 2008). One explanation of these observations is that indeed more fission aids the removal of these dysfunctional mitochondria.

Parallel findings in mammalian cell culture and Drosophila S2 cells suggest that under conditions where mitochondria are poisoned, Pink1 is stabilized on the mitochondrial outer membrane as to recruit Parkin (Korolchuk et al., 2007; D. P. Narendra et al., 2010; Ziviani et al., 2010). The stabilization of Pink1 then appears to trigger a series of events that results in the degradation of these sick mitochondria. Pink1 is a kinase and when Pink1 is stabilized on dysfunctional mitochondria, it phosphorylates Miro, a protein that mediates kinesin dependent mitochondrial transport (S. Liu et al., 2012; Tsai et al., 2014; Wang et al., 2011). Further work indicates that phosphorylated Miro is degraded by Parkin, an E3 ubiquitin ligase that is activated by the E2 conjugase Ube2A/Rad6 in mammalian cells and in flies (Haddad et al., 2013). Hence, the work conducted both in mammalian neurons and in flies, suggests that dysfunctional mitochondria fail to be transported in the cell. Stabilized Pink1 also targets other proteins: it recruits and phosphorylates Parkin (Shiba-Fukushima et al., 2012) and ubiquitin (Kane et al., 2014; Kazlauskaite et al., 2014; Koyano et al., 2014; Shiba-Fukushima et al., 2014), and Parkin then ubiquitinates mitochondrial targets that tag the organelle for degradation. The evidence indicates this pathway is implicated in mitochondrial quality control, but the targets ubiquitinated by Parkin including Mitofusin (Poole et al., 2010; Ziviani et al., 2010) and VDAC (Geisler et al., 2010; D. Narendra et al., 2010) also regulate mitochondrialendoplasmatic reticulum contacts (Rowland and Voeltz, 2012), further causing cellular dysfunction.

While this model is appealing, there are however also still a number of important but unanswered questions. For example, increased mitochondrial fission does not rescue the functional defects that are observed in pink1 mutant mitochondria, indicating that at least Pink1, also acts in other pathways of mitochondrial activity (Liu et al., 2011; Vilain et al., 2012). In addition, it has proven challenging to observe mitochondrial autophagy in vivo in neurons under nonartificial conditions, making it difficult to assess the in vivo importance of the process also during ageing. The recent development of killer red mitochondria may help to elucidate the process further. Here, killer red that is expressed in mitochondria creates ROS when excited and these ROS result in damage and the recruitment of parkin to these mitochondria (Ashrafi et al., 2014). Finally, if Pink1 is required to recruit Parkin to mitochondria to promote mitophagy, how is the overexpression of Parkin able to rescue the pink1 mutant phenotypes? Possibly alternative recruitment mechanisms or alternative autophagic strategies may exist and become upregulated, but these mechanisms, if they are relevant, remain to be studied in this context.

In healthy mitochondria much of the Pink1 protein is proteolytically cleaved by PARL (Whitworth et al., 2008). However, the remaining Pink1 appears to fulfill an important function. Work in mouse Pink1 knock out cells and in pink1 fly mutants indicates enzymatic defects in the electron transport chain (ETC) in the inner mitochondrial membrane (Gautier et al., 2008; Liu et al., 2011; Morais et al., 2009). The ETC transports electrons down their electrochemical gradient to establish a proton gradient over the inner mitochondrial membrane and this gradient is used by the mitochondrial ATPase to produce ATP. In pink1 mutant flies and cells, the enzymatic defects at the level of complex I result in a less negative 
mitochondrial membrane potential and less ATP production. Proteomic studies combined with in vivo rescue experiments in flies, mouse and patient derived cells subsequently provided evidence that pink1 deficiency results in defects to couple electron transport between complex I and ubiquinone (Morais et al., 2014). Both in flies and mammalian cells, the process of electron transfer at this level is facilitated by the phosphorylation of a specific complex I subunit NDUFA10, suggesting that therapeutic strategies that target this site may promote mitochondrial function (Morais et al., 2014; Pogson et al., 2014). Further supporting this model, in flies, the mitochondrial defects in pink1 mutants are rescued by expression of a yeast protein, NDI1 that is able to bypass electron transport in complex I by feeding electrons straight into complex III (Pogson et al., 2014; Vilain et al., 2012). Hence, a model emerges where Pink1 double-times between trying to maintaining high mitochondrial function and, when that fails, mediating Parkin dependent events.

\section{Using flies to find new treatments for PD}

Future work can now gear towards using this knowledge to start developing therapeutic strategies, also here, fruit flies have proven their value. Pink1 has been routinely used as a model, most likely because of pragmatic reasons: in flies pink1 is on the X-chromosome, facilitating genetic screens, but also because Pink1 has been intensely characterized and studied. It is likely that other PD models will follow in the future as well. Nonetheless, genetic screens in fruit flies and gene expression profiling in pink1 mutants have been very successful and they also further point to a mitochondrial connection. Indeed, the loss of Pink1 function activates a metabolic pathway that results in increased levels of nucleotides that appear to promote mitochondrial biogenesis, thereby suppressing the mitochondrial defects. Moreover, it was shown that enhancing nucleotide metabolism either genetically or using pharmacology is able to protect against mitochondrial dysfunction in pink1 mutants (Tufi et al., 2014). Further clinical studies will now need to be undertaken to assess the applicability of this approach in therapy.

An effective strategy to identify suppressors of the pink1 associated defects has been the use of genetic screening in fruit flies. Pink1 mutant flies do not fly well, likely because of mitochondrial defects in the muscle cells. Dominant suppressor screens then search for second site mutations (other than the pink1 mutation) that alleviate the defect in flight. This is a fast and effective way to identify suppressor loci, but the disadvantage is that such screens aim to identify factors that suppress the mitochondrial defects in pink1 mutant muscle cells, not neurons. Hence, neuron specific factors may be missed. Nonetheless, such screening approaches have identified numerous modifier loci (Esposito et al., 2013; Fernandes and Rao, 2011; S. Liu et al., 2012; Pogson et al., 2014; Thomas et al., 2014; Vos et al., 2012; Wu et al., 2013). For example, an enzyme that is involved in the production of vitamin $\mathrm{K} 2$ is a dosage sensitive modifier of the pink1 defects in flies. While vitamin K2 is best known for its role in blood coagulation, subsequent work indicated that vitamin $\mathrm{K} 2$ is also abundantly present in mitochondria, and that the compound acts as an alternative electron carrier molecule. In pink1 mutants, the action of vitamin K2 overcomes the ETC defect and results again in effective ATP production (Vos et al., 2012). Similarly, other strategies that improve mitochondrial function, including those that scavenge the ROS produced by the pink1 mutant mitochondria are protective. For example GST or removing Aconitase, a major mediator of ROS-induced toxicity in mitochondria are protective (Esposito et al., 2013; Kim and Yim, 2013; Whitworth et al., 2005). In addition, expression of Ret, TNF receptor-associated protein 1 (TRAP1) and near-infrared $808 \mathrm{~nm}$ light all turned out to improve mitochondrial function in Drosophila pink1 mutants thereby rescuing the cellular and behavioral defects in these animals (Klein et al., 2014; Vos et al., 2013; Zhang et al., 2013). These strategies are thus paving the way to a new generation of therapeutic strategies in Pink1-dependent strategies.

\section{Acknowledgments}

We would like to thank the members of the Verstreken lab for stimulating discussions and especially thank Sven Vilain for critical comments, helpful discussions and graphical support. Work in the Verstreken lab is supported by a European Research Council Starting Grant (ERC StG), the Fonds voor Wetenschappelijk Onderzoek Vlaanderen (FWO), the Hercules Foundation, the Instituut voor Wetenschap en Technologie (IWT), an Interuniversitaire Attractie Pool (IAP) by the Belgian Science Policy (BELSPO), the research fund of K.U. Leuven, a Methusalem grant of the Flemish government, and VIB. R.V. is supported by IWT [121324].

\section{References}

Ahle, S., Ungewickell, E., 1990. Auxilin, a newly identified clathrin-associated protein in coated vesicles from bovine brain. J. Cell Biol. 111, 19-29.

Ali, Y.O., Escala, W., Ruan, K., Zhai, R.G., 2011. Assaying locomotor, learning, and memory deficits in Drosophila models of neurodegeneration. J. Vis. Exp. 1-5. http://dx.doi.org/ $10.3791 / 2504$.

Ambroso, M.R., Hegde, B.G., Langen, R., 2014. Endophilin A1 induces different membrane shapes using a conformational switch that is regulated by phosphorylation. Proc. Natl. Acad. Sci. U. S. A. 111, 6982-6987. http://dx.doi.org/10.1073/pnas.1402233111.

Arranz, A.M., Delbroek, L., Van Kolen, K., Guimarães, M.R., Mandemakers, W., Daneels, G. Matta, S., Calafate, S., Shaban, H., Baatsen, P., De Bock, P.-J., Gevaert, K., Vanden Berghe, P., Verstreken, P., De Strooper, B., Moechars, D., 2014. LRRK2 functions in synaptic vesicle endocytosis through a kinase-dependent mechanism. J. Cell Sci. http://dx.doi.org/10.1242/jcs.158196.

Arthur, C.R., Morton, S.L., Dunham, L.D., Keeney, P.M., Bennett, J.P., 2009. Parkinson's disease brain mitochondria have impaired respirasome assembly, age-related increases in distribution of oxidative damage to mtDNA and no differences in heteroplasmic mtDNA mutation abundance. Mol. Neurodegener. 4 (37). http://dx.doi.org/10.1186/17501326-4-37.

Ashrafi, G., Schlehe, J.S., LaVoie, M.J., Schwarz, T.L., 2014. Mitophagy of damaged mitochondria occurs locally in distal neuronal axons and requires PINK1 and Parkin. J. Cell Biol. 206, 655-670. http://dx.doi.org/10.1083/jcb.201401070.

Athauda, D., Foltynie, T., 2014. The ongoing pursuit of neuroprotective therapies in Parkinson disease. Nat. Rev. Neurol. http://dx.doi.org/10.1038/nrneurol.2014.226.

Bassett, A.R., Tibbit, C., Ponting, C.P., Liu, J.-L., 2013. Highly efficient targeted mutagenesis of Drosophila with the CRISPR/Cas9 system. Cell Rep. 4, 220-228. http://dx.doi.org/10. 1016/j.celrep.2013.06.020.

Belenkaya, T.Y., Wu, Y., Tang, X., Zhou, B., Cheng, L., Sharma, Y.V., Yan, D., Selva, E.M., Lin, X., 2008. The retromer complex influences Wnt secretion by recycling wntless from endosomes to the trans-Golgi network. Dev. Cell 14, 120-131. http://dx.doi.org/10. 1016/j.devcel.2007.12.003.

Betarbet, R., Sherer, T.B., MacKenzie, G., Garcia-Osuna, M., Panov, A.V., Greenamyre, J.T., 2000 Chronic systemic pesticide exposure reproduces features of Parkinson's disease. Nat. Neurosci. 3, 1301-1306. http://dx.doi.org/10.1038/81834.

Bier, E., 2005. Drosophila, the golden bug, emerges as a tool for human genetics. Nat. Rev. Genet. 6, 9-23. http://dx.doi.org/10.1038/nrg1503.

Blandini, F., Armentero, M.-T., 2012. Animal models of Parkinson's disease. FEBS J. 279, 1156-1166. http://dx.doi.org/10.1111/j.1742-4658.2012.08491.x.

Bonifati, V., Rizzu, P., van Baren, M.J., Schaap, O., Breedveld, G.J., Krieger, E., Dekker, M.C.J Squitieri, F., Ibanez, P., Joosse, M., van Dongen, J.W., Vanacore, N., van Swieten, J.C., Brice, A., Meco, G., van Duijn, C.M., Oostra, B. a, Heutink, P., 2003. Mutations in the DJ-1 gene associated with autosomal recessive early-onset parkinsonism. Science 299, 256-259. http://dx.doi.org/10.1126/science.1077209.

Bové, J., Perier, C., 2012. Neurotoxin-based models of Parkinson's disease. Neuroscience 211, 51-76. http://dx.doi.org/10.1016/j.neuroscience.2011.10.057.

Brand, A.H., Perrimon, N., 1993. Targeted gene expression as a means of altering cell fates and generating dominant phenotypes. Development 118, 401-415.

Braschi, E., Goyon, V., Zunino, R., Mohanty, A., Xu, L., McBride, H.M., 2010. Vps35 mediates vesicle transport between the mitochondria and peroxisomes. Curr. Biol. 20, 1310-1315. http://dx.doi.org/10.1016/j.cub.2010.05.066.

Burchell, V.S., Nelson, D.E., Sanchez-Martinez, A., Delgado-Camprubi, M., Ivatt, R.M., Pogson, J.H., Randle, S.J., Wray, S., Lewis, P. a, Houlden, H., Abramov, A.Y., Hardy, J., Wood, N.W., Whitworth, A.J., Laman, H., Plun-Favreau, H., 2013. The Parkinson's disease-linked proteins Fbxo7 and Parkin interact to mediate mitophagy. Nat. Neurosci. 16, 1257-1265. http://dx.doi.org/10.1038/nn.3489.

Butler, E.K., Voigt, A., Lutz, A.K., Toegel, J.P., Gerhardt, E., Karsten, P., Falkenburger, B., Reinartz, A., Winklhofer, K.F., Schulz, J.B., 2012. The mitochondrial chaperone protein TRAP1 mitigates $\alpha$-Synuclein toxicity. PLoS Genet. 8, e1002488. http://dx.doi.org/10. 1371/journal.pgen.1002488.

Cao, G., Platisa, J., Pieribone, V. a, Raccuglia, D., Kunst, M., Nitabach, M.N., 2013. Genetically targeted optical electrophysiology in intact neural circuits. Cell 154, 904-913. http:// dx.doi.org/10.1016/j.cell.2013.07.027.

Cao, M., Milosevic, I., Giovedi, S., De Camilli, P., 2014. Upregulation of parkin in endophilin mutant mice. J. Neurosci. 34, 16544-16549. http://dx.doi.org/10.1523/JNEUROSCI. 1710-14.2014.

Cha, G.-H., Kim, S., Park, J., Lee, E., Kim, M., Lee, S.B., Kim, J.M., Chung, J., Cho, K.S., 2005. Parkin negatively regulates JNK pathway in the dopaminergic neurons of Drosophila. 
Proc. Natl. Acad. Sci. U. S. A. 102, 10345-10350. http://dx.doi.org/10.1073/pnas. 0500346102.

Chai, C., Lim, K., 2013. Genetic insights into sporadic Parkinson's disease pathogenesis. Curr. Genomics 14, 486-501. http://dx.doi.org/10.2174/1389202914666131210195808.

Chen, L., Feany, M.B., 2005. Alpha-synuclein phosphorylation controls neurotoxicity and inclusion formation in a Drosophila model of Parkinson disease. Nat. Neurosci. 8 , 657-663. http://dx.doi.org/10.1038/nn1443.

Chen, L., Periquet, M., Wang, X., Negro, A., McLean, P.J., Hyman, B.T., Feany, M.B., 2009. Tyrosine and serine phosphorylation of alpha-synuclein have opposing effects on neurotoxicity and soluble oligomer formation. J. Clin. Invest. 119, 3257-3265 http://dx.doi.org/10.1172/JCI39088.

Cirnaru, M.D., Marte, A., Belluzzi, E., Russo, I., Gabrielli, M., Longo, F., Arcuri, L., Murru, L., Bubacco, L., Matteoli, M., Fedele, E., Sala, C., Passafaro, M., Morari, M., Greggio, E., Onofri, F., Piccoli, G., 2014. LRRK2 kinase activity regulates synaptic vesicle trafficking and neurotransmitter release through modulation of LRRK2 macromolecular complex. Front. Mol. Neurosci. 7, 49. http://dx.doi.org/10.3389/ fnmol.2014.00049.

Clark, I.E., Dodson, M.W., Jiang, C., Cao, J.H., Huh, J.R., Seol, J.H., Yoo, S.J., Hay, B. a, Guo, M., 2006. Drosophila pink1 is required for mitochondrial function and interacts genetically with parkin. Nature 441, 1162-1166. http://dx.doi.org/10.1038/nature04779.

Costa, A.C., Loh, S.H.Y., Martins, L.M., 2013. Drosophila Trap1 protects against mitochondrial dysfunction in a PINK1/parkin model of Parkinson's disease. Cell Death Dis. 4, e467. http://dx.doi.org/10.1038/cddis.2012.205.

Cremona, O., Di Paolo, G., Wenk, M.R., Lüthi, A., Kim, W.T., Takei, K., Daniell, L., Nemoto, Y., Shears, S.B., Flavell, R. a, McCormick, D. a, De Camilli, P., 1999. Essential role of phosphoinositide metabolism in synaptic vesicle recycling. Cell 99, 179-188.

d'Amora, M., Angelini, C., Marcoli, M., Cervetto, C., Kitada, T., Vallarino, M., 2011. Expression of PINK1 in the brain, eye and ear of mouse during embryonic development J. Chem. Neuroanat. 41, 73-85. http://dx.doi.org/10.1016/j.jchemneu.2010.11.004.

Dai, Y., Clark, J., Zheng, K., Kujoth, G.C., Prolla, T. a, Simon, D.K., 2014. Somatic mitochondrial DNA mutations do not increase neuronal vulnerability to MPTP in young POLG mutator mice. Neurotoxicol. Teratol. 46C, 62-67. http://dx.doi.org/10.1016/j. ntt.2014.10.004.

Davie, C. a, 2008. A review of Parkinson's disease. Br. Med. Bull. 86, 109-127. http://dx.doi. org/10.1093/bmb/ldn013.

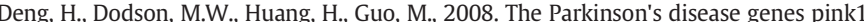
and parkin promote mitochondrial fission and/or inhibit fusion in Drosophila. Proc. Natl. Acad. Sci. U. S. A. 105, 14503-14508. http://dx.doi.org/10.1073/pnas. 0803998105.

Dickman, D.K., Lu, Z., Meinertzhagen, I. a, Schwarz, T.L., 2006. Altered synaptic development and active zone spacing in endocytosis mutants. Curr. Biol. 16, 591-598. http://dx.doi. org/10.1016/j.cub.2006.02.058.

Dodson, M.W., Zhang, T., Jiang, C., Chen, S., Guo, M., 2012. Roles of the Drosophila LRRK2 homolog in Rab7-dependent lysosomal positioning. Hum. Mol. Genet. 21, 1350-1363. http://dx.doi.org/10.1093/hmg/ddr573.

Dodson, M.W., Leung, L.K., Lone, M., Lizzio, M. a, Guo, M., 2014. Novel ethyl methanesulfonate (EMS)-induced null alleles of the Drosophila homolog of LRRK2 reveal a crucial role in endolysosomal functions and autophagy in vivo. Dis. Model. Mech. 7, 1351-1363. http://dx.doi.org/10.1242/dmm.017020.

Doxakis, E., 2010. Post-transcriptional regulation of alpha-synuclein expression by mir-7 and mir-153. J. Biol. Chem. 285, 12726-12734. http://dx.doi.org/10.1074/jbc.M109. 086827.

Edvardson, S., Cinnamon, Y., Ta-Shma, A., Shaag, A., Yim, Y.-I., Zenvirt, S., Jalas, C., Lesage S., Brice, A., Taraboulos, A., Kaestner, K.H., Greene, L.E., Elpeleg O, 2012. A deleterious mutation in DNAJC6 encoding the neuronal-specific clathrin-uncoating co-chaperone auxilin, is associated with juvenile parkinsonism. PLoS One 7, e36458. http://dx.doi. org/10.1371/journal.pone.0036458.

Engel, A.G., 2008. The neuromuscular junction. Handb. Clin. Neurol. 91, 103-148. http:// dx.doi.org/10.1016/S0072-9752(07)01503-5.

Esposito, G., Ana Clara, F., Verstreken, P., 2012. Synaptic vesicle trafficking and Parkinson's disease. Dev, Neurobiol. 72, 134-144. http://dx.doi.org/10.1002/dneu.20916.

Esposito, G., Vos, M., Vilain, S., Swerts, J., De Sousa Valadas, J., Van Meensel, S., Schaap, O., Verstreken, P., 2013. Aconitase causes iron toxicity in Drosophila pink1 mutants. PLoS Genet. 9, e1003478. http://dx.doi.org/10.1371/journal.pgen.1003478.

Eun, S.H., Lea, K., Overstreet, E., Stevens, S., Lee, J.-H., Fischer, J. a, 2007. Identification of genes that interact with Drosophila liquid facets. Genetics 175, 1163-1174. http:// dx.doi.org/10.1534/genetics.106.067959.

Eun, S.H., Banks, S.M.L., Fischer, J. a, 2008. Auxilin is essential for Delta signaling. Development 135, 1089-1095. http://dx.doi.org/10.1242/dev.009530.

Feany, M.B., Bender, W.W., 2000. A Drosophila model of Parkinson's disease. Nature 404 394-398. http://dx.doi.org/10.1038/35006074.

Fernandes, C., Rao, Y., 2011. Genome-wide screen for modifiers of Parkinson's disease genes in Drosophila. Mol. Brain 4, 17. http://dx.doi.org/10.1186/1756-6606-4-17.

Franch-Marro, X., Wendler, F., Guidato, S., Griffith, J., Baena-Lopez, A., Itasaki, N., Maurice, M.M., Vincent, J.-P., 2008. Wingless secretion requires endosome-to-Golgi retrieval of Wntless/Evi/Sprinter by the retromer complex. Nat. Cell Biol. 10, 170-177. http://dx. doi.org/10.1038/ncb1678.

Gautier, C. a, Kitada, T., Shen, J., 2008. Loss of PINK1 causes mitochondrial functiona defects and increased sensitivity to oxidative stress. Proc. Natl. Acad. Sci. U. S. A 105, 11364-11369. http://dx.doi.org/10.1073/pnas.0802076105.

Ge, L., Baskaran, S., Schekman, R., Hurley, J.H., 2014. The protein-vesicle network of autophagy. Curr. Opin. Cell Biol. 29, 18-24. http://dx.doi.org/10.1016/j.ceb. 2014.02.005.

Gehrke, S., Imai, Y., Sokol, N., Lu, B., 2010. Pathogenic LRRK2 negatively regulates microRNA-mediated translational repression. Nature 466, 637-641. http://dx.doi. org/10.1038/nature09191.
Geisler, S., Holmström, K.M., Skujat, D., Fiesel, F.C., Rothfuss, O.C., Kahle, P.J., Springer, W., 2010. PINK1/Parkin-mediated mitophagy is dependent on VDAC1 and p62/SQSTM1. Nat. Cell Biol. 12, 119-131. http://dx.doi.org/10.1038/ncb2012.

Gitler, A.D., Bevis, B.J., Shorter, J., Strathearn, K.E., Hamamichi, S., Su, L.J., Caldwell, K.A., Caldwell, G.A., Rochet, J.-C., McCaffery, J.M., Barlowe, C. Lindquist, S., 2008. The Parkinson's disease protein alpha-synuclein disrupts cellular Rab homeostasis. Proc. Natl. Acad. Sci. U. S. A. 105, 145-150. http://dx.doi.org/10.1073/pnas. 0710685105.

Gratz, S.J., Cummings, A.M., Nguyen, J.N., Hamm, D.C., Donohue, L.K., Harrison, M.M., Wildonger, J., O'Connor-Giles, K.M., 2013. Genome engineering of Drosophila with the CRISPR RNA-guided Cas9 nuclease. Genetics 194, 1029-1035. http://dx.doi.org/ 10.1534/genetics.113.152710.

Greene, J.C., Whitworth, A.J., Kuo, I., Andrews, L. a, Feany, M.B., Pallanck, L.J., 2003. Mitochondrial pathology and apoptotic muscle degeneration in Drosophila parkin mutants. Proc. Natl. Acad. Sci. U. S. A. 100, 4078-4083. http://dx.doi.org/10.1073/ pnas. 0737556100

Guo, S., Stolz, L.E., Lemrow, S.M., York, J.D., 1999. SAC1-like Domains of Yeast SAC1, INP52, and INP53 and of Human Synaptojanin Encode Polyphosphoinositide Phosphatases. J. Biol. Chem. 274, 12990-12995. http://dx.doi.org/10.1074/jbc.274.19.12990.

Gustavsson, A., Svensson, M., Jacobi, F., Allgulander, C., Alonso, J., Beghi, E., Dodel, R., Ekman, M., Faravelli, C., Fratiglioni, L., Gannon, B., Jones, D.H., Jennum, P., Jordanova, A., Jönsson, L., Karampampa, K., Knapp, M., Kobelt, G., Kurth, T., Lieb, R., Linde, M., Ljungcrantz, C., Maercker, A., Melin, B., Moscarelli, M., Musayev, A., Norwood, F., Preisig, M., Pugliatti, M., Rehm, J., Salvador-Carulla, L., Schlehofer, B., Simon, R., Steinhausen, H.-C., Stovner, L.J., Vallat, J.-M., Van den Bergh, P., van Os, J., Vos, P., Xu, W., Wittchen, H.-U., Jönsson, B., Olesen, J., 2011. Cost of disorders of the brain in Europe 2010. Eur. Neuropsychopharmacol. 21, 718-779. http://dx.doi.org/10. 1016/j.euroneuro.2011.08.008.

Haddad, D.M., Vilain, S., Vos, M., Esposito, G., Matta, S., Kalscheuer, V.M., Craessaerts, K, Leyssen, M., Nascimento, R.M.P., Vianna-Morgante, A.M., De Strooper, B., Van Esch, H., Morais, V. a, Verstreken, P., 2013. Mutations in the intellectual disability gene Ube2a cause neuronal dysfunction and impair parkin-dependent mitophagy. Mol. Cell 50, 831-843. http://dx.doi.org/10.1016/j.molcel.2013.04.012.

Hagedorn, E.J., Bayraktar, J.L., Kandachar, V.R., Bai, T., Englert, D.M., Chang, H.C., 2006. Drosophila melanogaster auxilin regulates the internalization of Delta to control activity of the Notch signaling pathway. J. Cell Biol. 173, 443-452. http://dx.doi.org/ $10.1083 /$ jcb.200602054.

Hao, L.-Y., Giasson, B.I., Bonini, N.M., 2010. DJ-1 is critical for mitochondrial function and rescues PINK1 loss of function. Proc. Natl. Acad. Sci. U. S. A. 107, 9747-9752. http://dx. doi.org/10.1073/pnas.0911175107.

Harris, T.W., Hartwieg, E., Horvitz, H.R., Jorgensen, E.M., 2000. Mutations in synaptojanin disrupt synaptic vesicle recycling. J. Cell Biol. 150, 589-600.

Haywood, A.F.M., Staveley, B.E., 2004. Parkin counteracts symptoms in a Drosophila model of Parkinson's disease. BMC Neurosci. 5, 14. http://dx.doi.org/10.1186/14712202-5-14.

Hirsch, E., Graybiel, A.M., Agid, Y.A., 1988. Melanized dopaminergic neurons are differentially susceptible to degeneration in Parkinson's disease. Nature 334, 345-348. http:// dx.doi.org/10.1038/334345a0.

Hirst, J., Sahlender, D. a, Li, S., Lubben, N.B., Borner, G.H.H., Robinson, M.S., 2008. Auxilin depletion causes self-assembly of clathrin into membraneless cages in vivo. Traffic 9, 1354-1371. http://dx.doi.org/10.1111/j.1600-0854.2008.00764.x.

Humphrey, D.M., Parsons, R.B., Ludlow, Z.N., Riemensperger, T., Esposito, G., Verstreken, P., Jacobs, H.T., Birman, S., Hirth, F., 2012. Alternative oxidase rescues mitochondriamediated dopaminergic cell loss in Drosophila. Hum. Mol. Genet. 21, 2698-2712. http://dx.doi.org/10.1093/hmg/dds096.

Igaki, T., Suzuki, Y., Tokushige, N., Aonuma, H., Takahashi, R., Miura, M., 2007. Evolution of mitochondrial cell death pathway: proapoptotic role of HtrA2/Omi in Drosophila. Biochem. Biophys. Res. Commun. 356, 993-997. http://dx.doi.org/10.1016/j.bbrc. 2007.03.079.

Imai, Y., Gehrke, S., Wang, H.-Q., Takahashi, R., Hasegawa, K., Oota, E., Lu, B., 2008. Phosphorylation of 4E-BP by LRRK2 affects the maintenance of dopaminergic neurons in Drosophila. EMBO J. 27, 2432-2443. http://dx.doi.org/10.1038/emboj.2008.163.

Irrcher, I., Aleyasin, H., Seifert, E.L., Hewitt, S.J., Chhabra, S., Phillips, M., Lutz, a K., Rousseaux, M.W.C., Bevilacqua, L., Jahani-Asl, A., Callaghan, S., MacLaurin, J.G., Winklhofer, K.F., Rizzu, P., Rippstein, P., Kim, R.H., Chen, C.X., Fon, E. a, Slack, R.S., Harper, M.E., McBride, H.M., Mak, T.W., Park, D.S., 2010. Loss of the Parkinson's disease-linked gene DJ-1 perturbs mitochondrial dynamics. Hum. Mol. Genet. 19, 3734-3746. http://dx.doi.org/ $10.1093 / \mathrm{hmg} / \mathrm{ddq} 288$

Jost, M., Simpson, F., Kavran, J.M., Lemmon, M. a, Schmid, S.L., 1998. Phosphatidylinositol4,5-bisphosphate is required for endocytic coated vesicle formation. Curr. Biol. 8, 1399-1402. http://dx.doi.org/10.1016/S0960-9822(98)00022-0.

Junn, E., Lee, K.-W., Jeong, B.S., Chan, T.W., Im, J.-Y., Mouradian, M.M., 2009. Repression of alpha-synuclein expression and toxicity by microRNA-7. Proc. Natl. Acad. Sci. U. S. A. 106, 13052-13057. http://dx.doi.org/10.1073/pnas.0906277106.

Kandachar, V., Bai, T., Chang, H.C., 2008. The clathrin-binding motif and the J-domain of Drosophila Auxilin are essential for facilitating Notch ligand endocytosis. BMC Dev. Biol. 8, 50. http://dx.doi.org/10.1186/1471-213X-8-50.

Kane, L. a, Lazarou, M., Fogel, A.I., Li, Y., Yamano, K., Sarraf, S. a, Banerjee, S., Youle, R.J., 2014. PINK1 phosphorylates ubiquitin to activate Parkin E3 ubiquitin ligase activity. J. Cell Biol. 205, 143-153. http://dx.doi.org/10.1083/jcb.201402104.

Karpinar, D.P., Balija, M.B.G., Kügler, S., Opazo, F., Rezaei-Ghaleh, N., Wender, N., Kim, H.-Y Taschenberger, G., Falkenburger, B.H., Heise, H., Kumar, A, Riedel, D., Fichtner, L. Voigt, A., Braus, G.H., Giller, K., Becker, S., Herzig, A., Baldus, M., Jäckle, H., Eimer, S., Schulz, J.B., Griesinger, C., Zweckstetter, M., 2009. Pre-fibrillar alpha-synuclein variants with impaired beta-structure increase neurotoxicity in Parkinson's disease models. EMBO J. 28, 3256-3268. http://dx.doi.org/10.1038/emboj.2009.257. 
Kawajiri, S., Saiki, S., Sato, S., Sato, F., Hatano, T., Eguchi, H., Hattori, N., 2010. PINK1 is recruited to mitochondria with parkin and associates with LC3 in mitophagy. FEBS Lett. 584, 1073-1079. http://dx.doi.org/10.1016/j.febslet.2010.02.016.

Kazlauskaite, A., Kondapalli, C., Gourlay, R., Campbell, D.G., Ritorto, M.S., Hofmann, K., Alessi, D.R., Knebel, A., Trost, M., Muqit, M.M.K., 2014. Parkin is activated by PINK1dependent phosphorylation of ubiquitin at Ser65. Biochem. J. 460, 127-139. http:// dx.doi.org/10.1042/BJ20140334.

Keeney, P.M., Xie, J., Capaldi, R. a, Bennett, J.P., 2006. Parkinson's disease brain mitochondrial complex I has oxidatively damaged subunits and is functionally impaired and misassembled. J. Neurosci. 26, 5256-5264. http://dx.doi.org/10.1523/JNEUROSCI. 0984-06.2006.

Khan, F.S., Fujioka, M., Datta, P., Fernandes-Alnemri, T., Jaynes, J.B., Alnemri, E.S., 2008. The interaction of DIAP1 with dOmi/HtrA2 regulates cell death in Drosophila. Cell Death Differ. 15, 1073-1083. http://dx.doi.org/10.1038/cdd.2008.19.

Kim, K., Yim, J., 2013. Glutathione S-transferase omega suppresses the defective phenotypes caused by PINK1 loss-of-function in Drosophila. Biochem. Biophys. Res. Commun. 437, 615-619. http://dx.doi.org/10.1016/j.bbrc.2013.07.011.

Kim, R.H., Peters, M., Jang, Y., Shi, W., Pintilie, M., Fletcher, G.C., DeLuca, C., Liepa, J., Zhou, L., Snow, B., Binari, R.C., Manoukian, A.S., Bray, M.R., Liu, F.-F., Tsao, M.-S., Mak, T.W. 2005. DJ-1, a novel regulator of the tumor suppressor PTEN. Cancer Cell 7, 263-273. http://dx.doi.org/10.1016/j.ccr.2005.02.010.

Kim, Y., Park, J., Kim, S., Song, S., Kwon, S.-K., Lee, S.-H., Kitada, T., Kim, J.-M., Chung, J. 2008. PINK1 controls mitochondrial localization of Parkin through direct phosphorylation. Biochem. Biophys. Res. Commun. 377, 975-980. http://dx.doi.org/10.1016/j. bbrc.2008.10.104.

Kitada, T., Asakawa, S., Hattori, N., Matsumine, H., Yamamura, Y., Minoshima, S., Yokochi, M., Mizuno, Y., Shimizu, N., 1998. Mutations in the parkin gene cause autosomal recessive juvenile parkinsonism. Nature 392, 605-608. http://dx.doi.org/10.1038/33416.

Klein, P., Müller-Rischart, A.K., Motori, E., Schönbauer, C., Schnorrer, F., Winklhofer, K.F. Klein, R., 2014. Ret rescues mitochondrial morphology and muscle degeneration of Drosophila Pink1 mutants. EMBO J. 33, 341-355. http://dx.doi.org/10.1002/embj. 201284290.

Koch, M., Holt, M., 2012. Coupling exo- and endocytosis: an essential role for $\mathrm{PIP}_{2}$ at the synapse. Biochim. Biophys. Acta 1821, 1114-1132. http://dx.doi.org/10.1016/j. bbalip.2012.02.008.

Kontopoulos, E., Parvin, J.D., Feany, M.B., 2006. Alpha-synuclein acts in the nucleus to inhibit histone acetylation and promote neurotoxicity. Hum. Mol. Genet. 15, 3012-3023. http://dx.doi.org/10.1093/hmg/ddl243.

Korolchuk, V.I., Schütz, M.M., Gómez-Llorente, C., Rocha, J., Lansu, N.R., Collins, S.M., Wairkar, Y.P., Robinson, I.M., O'Kane, C.J., 2007. Drosophila Vps35 function is necessary for normal endocytic trafficking and actin cytoskeleton organisation. J. Cell Sci. 120, 4367-4376. http://dx.doi.org/10.1242/jcs.012336.

Kowal, S.L., Dall, T.M., Chakrabarti, R., Storm, M.V., Jain, A., 2013. The current and projected economic burden of Parkinson's disease in the United States. Mov. Disord. 28 311-318. http://dx.doi.org/10.1002/mds.25292.

Koyano, F., Okatsu, K., Kosako, H., Tamura, Y., Go, E., Kimura, M., Kimura, Y., Tsuchiya, H., Yoshihara, H., Hirokawa, T., Endo, T., Fon, E. a, Trempe, J.-F., Saeki, Y., Tanaka, K., Matsuda, N., 2014. Ubiquitin is phosphorylated by PINK1 to activate parkin. Nature 510, 162-166. http://dx.doi.org/10.1038/nature13392.

Krebs, C.E., Karkheiran, S., Powell, J.C., Cao, M., Makarov, V., Darvish, H., Di Paolo, G. Walker, R.H., Shahidi, G.A., Buxbaum, J.D., De Camilli, P., Yue, Z., Paisán-Ruiz, C., 2013. The Sac1 domain of SYNJ1 identified mutated in a family with early-onset progressive Parkinsonism with generalized seizures. Hum. Mutat. 34, 1200-1207. http://dx.doi.org/10.1002/humu.22372

Kühn, K., Zhu, X.-R., Lübbert, H., Stichel, C.C., 2004. Parkin expression in the developing mouse. Brain Res. Dev. Brain Res. 149, 131-142. http://dx.doi.org/10.1016/j. devbrainres.2004.02.001.

Langston, J.W., Ballard, P., Tetrud, J.W., Irwin, I., 1983. Chronic Parkinsonism in humans due to a product of meperidine-analog synthesis. Science 219, 979-980

Lavara-Culebras, E., Paricio, N., 2007. Drosophila DJ-1 mutants are sensitive to oxidative stress and show reduced lifespan and motor deficits. Gene 400, 158-165. http://dx. doi.org/10.1016/j.gene.2007.06.013.

Lawal, H.O., Chang, H.-Y., Terrell, A.N., Brooks, E.S., Pulido, D., Simon, A.F., Krantz, D.E., 2010. The Drosophila vesicular monoamine transporter reduces pesticide-induced loss of dopaminergic neurons. Neurobiol. Dis. 40, 102-112. http://dx.doi.org/10. 1016/j.nbd.2010.05.008.

Lee, S.B., Kim, W., Lee, S., Chung, J., 2007. Loss of LRRK2/PARK8 induces degeneration of dopaminergic neurons in Drosophila. Biochem. Biophys. Res. Commun. 358, 534-539. http://dx.doi.org/10.1016/j.bbrc.2007.04.156.

Lesage, S., Brice, A., 2012. Role of mendelian genes in "sporadic" Parkinson's disease Parkinsonism Relat. Disord. 18 (Suppl. 1), S66-S70. http://dx.doi.org/10.1016 S1353-8020(11)70022-0.

Lin, C.-H., Tsai, P.-I., Wu, R.-M., Chien, C.-T., 2010. LRRK2 G2019S mutation induces dendrite degeneration through mislocalization and phosphorylation of tau by recruiting autoactivated GSK3ß. J. Neurosci. 30, 13138-13149. http://dx.doi.org/10.1523/ JNEUROSCI. 1737-10.2010.

Linhart, R., Wong, S.A., Cao, J., Tran, M., Huynh, A., Ardrey, C., Park, J.M., Hsu, C., Taha, S. Peterson, R., Shea, S., Kurian, J., Venderova, K., 2014. Vacuolar protein sorting 35 (Vps35) rescues locomotor deficits and shortened lifespan in Drosophila expressing a Parkinson's disease mutant of Leucine-Rich Repeat Kinase 2 (LRRK2). Mol. Neurodegener. 9, 23. http://dx.doi.org/10.1186/1750-1326-9-23.

Liu, Y., Lehmann, M., 2008. A genomic response to the yeast transcription factor GAL4 in Drosophila. Fly (Austin) 2, 92-98.

Liu, W., Acín-Peréz, R., Geghman, K.D., Manfredi, G., Lu, B., Li, C., 2011. Pink1 regulates the oxidative phosphorylation machinery via mitochondrial fission. Proc. Natl. Acad. Sci. U. S. A. 108, 12920-12924. http://dx.doi.org/10.1073/pnas.1107332108.
Liu, J., Li, C., Yu, Z., Huang, P., Wu, H., Wei, C., Zhu, N., Shen, Y., Chen, Y., Zhang, B., Deng, W.-M., Jiao, R., 2012a. Efficient and specific modifications of the Drosophila genome by means of an easy TALEN strategy. J. Genet. Genomics 39, 209-215. http://dx.doi. org/10.1016/j.jgg.2012.04.003.

Liu, S., Sawada, T. Lee, S., Yu, W., Silverio, G., Alapatt, P., Millan, I., Shen, A., Saxton, W. Kanao, T., Takahashi, R., Hattori, N., Imai, Y., Lu, B., 2012b. Parkinson's diseaseassociated kinase PINK1 regulates Miro protein level and axonal transport of mitochondria. PLoS Genet. 8, e1002537. http://dx.doi.org/10.1371/journal.pgen.1002537.

Liu, J., Chen, Y., Jiao, R., 2014. TALEN-mediated Drosophila genome editing: protocols and applications. Methods 69, 22-31. http://dx.doi.org/10.1016/j.ymeth.2014.04.010

Lohmann, E., Periquet, M., Bonifati, V., Wood, N.W., De Michele, G., Bonnet, A., Fraix, V., Broussolle, E., Horstink, M.W.I.M., Vidailhet, M., Verpillat, P., Gasser, T., Nicholl, D. Teive, H., Raskin, S., Rascol, O., Destée, A., Ruberg, M., Gasparini, F., Meco, G., Agid Y., Durr, A., Brice, A., 2003. How much phenotypic variation can be attributed to parkin genotype? Ann. Neurol. 54, 176-185. http://dx.doi.org/10.1002/ana.10613.

Lotharius, J., O'Malley, K.L., 2000. The parkinsonism-inducing drug 1-methyl-4phenylpyridinium triggers intracellular dopamine oxidation. A novel mechanism of toxicity. J. Biol. Chem. 275, 38581-38588. http://dx.doi.org/10.1074/jbc.M005385200.

Ma, L., Wei, L., Wu, F., Hu, Z., Liu, Z., Yuan, W., 2013. Advances with microRNAs in Parkinson's disease research. Drug Des. Devel. Ther. 7, 1103-1113. http://dx.doi. org/10.2147/DDDT.S48500.

MacLeod, D.A., Rhinn, H., Kuwahara, T., Zolin, A., Di Paolo, G., McCabe, B.D., MacCabe, B.D. Marder, K.S., Honig, L.S., Clark, L.N., Small, S.A., Abeliovich, A., 2013. RAB7L1 interacts with LRRK2 to modify intraneuronal protein sorting and Parkinson's disease risk Neuron 77, 425-439. http://dx.doi.org/10.1016/j.neuron.2012.11.033.

Malhotra, A., Edelman-Novemsky, I., Xu, Y., Plesken, H., Ma, J., Schlame, M., Ren, M., 2009. Role of calcium-independent phospholipase A2 in the pathogenesis of Barth syndrome. Proc Natl. Acad. Sci. U. S. A. 106, 2337-2341. http://dx.doi.org/10.1073/pnas.0811224106.

Mandemakers, W., Snellinx, A., O'Neill, M.J., de Strooper, B., 2012. LRRK2 expression is enriched in the striosomal compartment of mouse striatum. Neurobiol. Dis. 48 582-593. http://dx.doi.org/10.1016/j.nbd.2012.07.017.

Marras, C., Lohmann, K., Lang, A., Klein, C., 2012. Fixing the broken system of genetic locus symbols: Parkinson disease and dystonia as examples. Neurology 78, 1016-1024 http://dx.doi.org/10.1212/WNL.0b013e31824d58ab.

Martin, I., Kim, J.W., Lee, B.D., Kang, H.C., Xu, J.-C., Jia, H., Stankowski, J., Kim, M.-S., Zhong, J., Kumar, M., Andrabi, S. a, Xiong, Y., Dickson, D.W., Wszolek, Z.K., Pandey, A., Dawson, T.M., Dawson, V.L., 2014. Ribosomal protein s15 phosphorylation mediates LRRK2 neurodegeneration in Parkinson's disease. Cell 157, 472-485. http://dx.doi org/10.1016/j.cell.2014.01.064.

Matta, S., Van Kolen, K., da Cunha, R., van den Bogaart, G., Mandemakers, W., Miskiewicz K., De Bock, P.-J., Morais, V. a, Vilain, S., Haddad, D., Delbroek, L., Swerts, J., ChávezGutiérrez, L., Esposito, G., Daneels, G., Karran, E., Holt, M., Gevaert, K., Moechars, D.W., De Strooper, B., Verstreken, P., 2012. LRRK2 controls an EndoA phosphorylation cycle in synaptic endocytosis. Neuron 75, 1008-1021. http://dx.doi.org/10.1016/j. neuron.2012.08.022

McLean, P.J., Kawamata, H., Ribich, S., Hyman, B.T., 2000. Membrane association and protein conformation of alpha-synuclein in intact neurons. Effect of Parkinson's disease-linked mutations. J. Biol. Chem. 275, 8812-8816. http://dx.doi.org/10.1074/jbc.275.12.8812.

McPherson, P.S., Garcia, E.P., Slepnev, V.I., David, C., Zhang, X., Grabs, D., Sossin, W.S. Bauerfeind, R., Nemoto, Y., De Camilli, P., 1996. A presynaptic inositol-5-phosphatase. Nature 379, 353-357. http://dx.doi.org/10.1038/379353a0.

Menzies, F.M., Yenisetti, S.C., Min, K.-T., 2005. Roles of Drosophila DJ-1 in survival of dopaminergic neurons and oxidative stress. Curr. Biol. 15, 1578-1582. http://dx.doi org/10.1016/j.cub.2005.07.036.

Meulener, M., Whitworth, A.J., Armstrong-Gold, C.E., Rizzu, P., Heutink, P., Wes, P.D. Pallanck, L.J., Bonini, N.M., 2005. Drosophila DJ-1 mutants are selectively sensitive to environmental toxins associated with Parkinson's disease. Curr. Biol. 15, 1572-1577. http://dx.doi.org/10.1016/j.cub.2005.07.064.

Miñones-Moyano, E., Porta, S., Escaramís, G., Rabionet, R., Iraola, S., Kagerbauer, B., Espinosa-Parrilla, Y., Ferrer, I., Estivill, X., Martí, E., 2011. MicroRNA profiling of Parkinson's disease brains identifies early downregulation of miR-34b/c which modulate mitochondrial function. Hum. Mol. Genet. 20, 3067-3078. http://dx.doi.org/10 1093/hmg/ddr210.

Miura, E., Hasegawa, T. Konno, M Suzuki, M. Sugeno, N, Fujikake, N Geisler, S. Tabuchi, M., Oshima, R., Kikuchi, A., Baba, T., Wada, K., Nagai, Y., Takeda, A., Aoki, M., 2014 VPS35 dysfunction impairs lysosomal degradation of $\alpha$-synuclein and exacerbates neurotoxicity in a Drosophila model of Parkinson's disease. Neurobiol. Dis. 71, 1-13. http://dx.doi.org/10.1016/j.nbd.2014.07.014.

Morais, V. a, Verstreken, P., Roethig, A., Smet, J., Snellinx, A., Vanbrabant, M., Haddad, D. Frezza, C., Mandemakers, W., Vogt-Weisenhorn, D., Van Coster, R., Wurst, W. Scorrano, L., De Strooper, B., 2009. Parkinson's disease mutations in PINK1 result in decreased Complex I activity and deficient synaptic function. EMBO Mol. Med. 1, 99-111. http://dx.doi.org/10.1002/emmm.200900006.

Morais, V.A., Haddad, D., Craessaerts, K., De Bock, P.-J., Swerts, J., Vilain, S., Aerts, L. Overbergh, L., Grünewald, A., Seibler, P., Klein, C., Gevaert, K., Verstreken, P., De Strooper, B., 2014. PINK1 loss-of-function mutations affect mitochondrial complex activity via NdufA10 ubiquinone uncoupling. Science 344, 203-207. http://dx.doi. org/10.1126/science.1249161.

Mouradian, M.M. 2012. MicroRNAs in Parkinson's disease. Neurobiol. Dis. 46, 279-284 http://dx.doi.org/10.1016/j.nbd.2011.12.046.

Muñoz-Soriano, V., Paricio, N., 2007. Overexpression of Septin 4, the Drosophila homologue of human CDCrel-1, is toxic for dopaminergic neurons. Eur. J. Neurosci. 26, 3150-3158. http://dx.doi.org/10.1111/j.1460-9568.2007.05937.x.

Narendra, D., Tanaka, A., Suen, D.-F., Youle, R.J., 2009. Parkin-induced mitophagy in the pathogenesis of Parkinson disease. Autophagy 5, 706-708. http://dx.doi.org/10.4161/ auto.5.5.8505. 
Narendra, D., Kane, L. a, Hauser, D.N., Fearnley, I.M., Youle, R.J., 2010a. p62/SOSTM1 is required for Parkin-induced mitochondrial clustering but not mitophagy; VDAC1 is dispensable for both. Autophagy 6, 1090-1106. http://dx.doi.org/10.4161/auto.6.8 13426.

Narendra, D.P., Jin, S.M., Tanaka, A., Suen, D.-F., Gautier, C. a, Shen, J., Cookson, M.R., Youle, R.J., 2010b. PINK1 is selectively stabilized on impaired mitochondria to activate Parkin. PLoS Biol. 8, e1000298. http://dx.doi.org/10.1371/journal.pbio. 1000298.

Naydenov, A.V., Vassoler, F., Luksik, A.S., Kaczmarska, J., Konradi, C., 2010. Mitochondrial abnormalities in the putamen in Parkinson's disease dyskinesia. Acta Neuropathol 120, 623-631. http://dx.doi.org/10.1007/s00401-010-0740-8.

Ng, C.-H., Mok, S.Z.S., Koh, C., Ouyang, X., Fivaz, M.L., Tan, E.-K., Dawson, V.L., Dawson, T.M., Yu, F., Lim, K.-L., 2009. Parkin protects against LRRK2 G2019S mutant-induced dopaminergic neurodegeneration in Drosophila. J. Neurosci. 29, 11257-11262. http://dx.doi.org/10.1523/JNEUROSCI. 2375-09.2009.

Orsucci, D., Caldarazzo Ienco, E., Mancuso, M., Siciliano, G., 2011. POLG1-related and other "mitochondrial Parkinsonisms": an overview. J. Mol. Neurosci. 44, 17-24. http://dx doi.org/10.1007/s12031-010-9488-9.

Ossig, C., Reichmann, H., 2015. Treatment strategies in early and advanced Parkinson disease. Neurol. Clin. 33, 19-37. http://dx.doi.org/10.1016/j.ncl.2014.09.009.

Paisán-Ruíz, C., Jain, S., Evans, E.W., Gilks, W.P., Simón, J., van der Brug, M., López de Munain A., Aparicio, S., Gil, A.M., Khan, N., Johnson, J., Martinez, J.R., Nicholl, D., Carrera, I.M., Pena, A.S., de Silva, R. Lees, A., Martí-Massó, J.F., Pérez-Tur, J., Wood, N.W., Singleton, A.B., 2004. Cloning of the gene containing mutations that cause PARK8-linked Parkinson's disease. Neuron 44, 595-600. http://dx.doi.org/10.1016/j.neuron.2004.10. 023.

Paisan-Ruiz, C., Bhatia, K.P., Li, A., Hernandez, D., Davis, M., Wood, N.W., Hardy, J. Houlden, H., Singleton, A., Schneider, S. a, 2009. Characterization of PLA2G6 as a locus for dystonia-parkinsonism. Ann. Neurol. 65, 19-23. http://dx.doi.org/10.1002/ ana. 21415.

Park, J., Kim, S.Y., Cha, G.-H., Lee, S.B., Kim, S., Chung, J., 2005. Drosophila DJ-1 mutants show oxidative stress-sensitive locomotive dysfunction. Gene 361, 133-139. http:// dx.doi.org/10.1016/j.gene.2005.06.040.

Park, J., Lee, S.B., Lee, S., Kim, Y., Song, S., Kim, S., Bae, E., Kim, J., Shong, M., Kim, J.M., Chung, J., 2006. Mitochondrial dysfunction in Drosophila PINK1 mutants is complemented by parkin. Nature 441, 1157-1161. http://dx.doi.org/10.1038/ nature04788.

Pesah, Y., Pham, T., Burgess, H., Middlebrooks, B., Verstreken, P., Zhou, Y., Harding, M. Bellen, H., Mardon, G., 2004. Drosophila parkin mutants have decreased mass and cell size and increased sensitivity to oxygen radical stress. Development 131 2183-2194. http://dx.doi.org/10.1242/dev.01095.

Piccoli, G., Condliffe, S.B., Bauer, M., Giesert, F., Boldt, K., De Astis, S., Meixner, A., Sarioglu, H. Vogt-Weisenhorn, D.M., Wurst, W., Gloeckner, C.J., Matteoli, M., Sala, C., Ueffing M., 2011. LRRK2 controls synaptic vesicle storage and mobilization within the recycling pool. J. Neurosci. 31, 2225-2237. http://dx.doi.org/10.1523/JNEUROSCI. 3730-10.2011.

Pogson, J.H., Ivatt, R.M., Sanchez-Martinez, A., Tufi, R., Wilson, E., Mortiboys, H. Whitworth, A.J., 2014. The complex I subunit NDUFA10 selectively rescues Drosophila pink1 mutants through a mechanism independent of mitophagy. PLoS Genet. 10, e1004815. http://dx.doi.org/10.1371/journal.pgen.1004815.

Polymeropoulos, M.H., Lavedan, C., Leroy, E., Ide, S.E., Dehejia, A., Dutra, A., Pike, B., Root H., Rubenstein, J., Boyer, R., Stenroos, E.S., Chandrasekharappa, S., Athanassiadou, A Papapetropoulos, T., Johnson, W.G., Lazzarini, A.M., Duvoisin, R.C., Di Iorio, G., Golbe, LI, Nussbaum, R.L, 1997. Mutation in the alpha-synuclein gene identified in families with Parkinson's disease. Science 276, 2045-2047.

Poole, A.C., Thomas, R.E., Andrews, L. a, McBride, H.M., Whitworth, A.J., Pallanck, L.J., 2008 The PINK1/Parkin pathway regulates mitochondrial morphology. Proc. Natl. Acad. Sci. U. S. A. 105, 1638-1643. http://dx.doi.org/10.1073/pnas.0709336105.

Poole, A.C., Thomas, R.E., Yu, S., Vincow, E.S., Pallanck, L., 2010. The mitochondria fusion-promoting factor mitofusin is a substrate of the PINK1/parkin pathway. PLoS One 5, e10054. http://dx.doi.org/10.1371/journal.pone.0010054.

Port, F., Kuster, M., Herr, P., Furger, E., Bänziger, C., Hausmann, G., Basler, K., 2008. Wingless secretion promotes and requires retromer-dependent cycling of Wntless. Nat Cell Biol. 10, 178-185. http://dx.doi.org/10.1038/ncb1687.

Pridgeon, J.W., Olzmann, J. a, Chin, L.-S., Li, L., 2007. PINK1 protects against oxidative stress by phosphorylating mitochondrial chaperone TRAP1. PLoS Biol. 5, e172. http://dx.doi. org/10.1371/journal.pbio.0050172.

Quadri, M., Fang, M., Picillo, M., Olgiati, S., Breedveld, G.J., Graafland, J., Wu, B., Xu, F., Erro R., Amboni, M., Pappatà, S., Quarantelli, M., Annesi, G., Quattrone, A., Chien, H.F. Barbosa, E.R., Oostra, B. a, Barone, P., Wang, J., Bonifati, V., 2013. Mutation in the SYNJ1 gene associated with autosomal recessive, early-onset Parkinsonism. Hum. Mutat. 34, 1208-1215. http://dx.doi.org/10.1002/humu.22373.

Ramachandran, P., Budnik, V., 2010. Electron microscopy of Drosophila larval neuromuscular junctions. Cold Spring Harb. Protoc. 5 (8) (pdb.prot5474).

Ramirez, A., Heimbach, A., Gründemann, J., Stiller, B., Hampshire, D., Cid, L.P., Goebel, I., Mubaidin, A.F., Wriekat, A.-L., Roeper, J., Al-Din, A., Hillmer, A.M., Karsak, M., Liss, B. Woods, C.G., Behrens, M.I., Kubisch, C., 2006. Hereditary parkinsonism with dementia is caused by mutations in ATP13A2, encoding a lysosomal type 5 P-type ATPase. Nat. Genet. 38, 1184-1191. http://dx.doi.org/10.1038/ng1884

Ren, X., Yang, Z., Xu, J., Sun, J., Mao, D., Hu, Y., Yang, S.-J., Qiao, H.-H., Wang, X., Hu, Q. Deng, P., Liu, L.-P., Ji, J.-Y., Li, J.B., Ni, J.-Q., 2014. Enhanced specificity and efficiency of the CRISPR/Cas9 system with optimized soRNA parameters in Drosophila. Cell Rep. 9, 1151-1162. http://dx.doi.org/10.1016/j.celrep.2014.09.044.

Ringstad, N., Nemoto, Y., De Camilli, P., 1997. The SH3p4/Sh3p8/SH3p13 protein family: binding partners for synaptojanin and dynamin via a Grb2-like Src homology 3 domain. Proc. Natl. Acad. Sci. U. S. A. 94, 8569-8574.
Rowland, A. a, Voeltz, G.K., 2012. Endoplasmic reticulum-mitochondria contacts: function of the junction. Nat. Rev. Mol. Cell Biol. 13, 607-625. http://dx.doi.org/10.1038/ nrm3440.

Scheele, U., Kalthoff, C., Ungewickell, E., 2001. Multiple interactions of auxilin 1 with clathrin and the AP-2 adaptor complex. J. Biol. Chem. 276, 36131-36138, http://dx. doi.org/10.1074/jbc.M106511200.

Schertel, C., Huang, D., Björklund, M., Bischof, J., Yin, D., Li, R., Wu, Y., Zeng, R., Wu, J., Taipale, J., Song, H., Basler, K., 2013. Systematic screening of a Drosophila ORF library in vivo uncovers Wnt/Wg pathway components. Dev. Cell 25, 207-219. http://dx.doi. org/10.1016/j.devcel.2013.02.019.

Schneider, S.A., Obeso, J.A., 2014. Clinical and pathological features of Parkinson's disease. Curr. Top. Behav. Neurosci. http://dx.doi.org/10.1007/7854_2014_317.

Shiba-Fukushima, K., Imai, Y., Yoshida, S., Ishihama, Y., Kanao, T., Sato, S., Hattori, N., 2012. PINK1-mediated phosphorylation of the Parkin ubiquitin-like domain primes mitochondrial translocation of Parkin and regulates mitophagy. Sci. Rep. 2, 1002. http:// dx.doi.org/10.1038/srep01002.

Shiba-Fukushima, K., Arano, T., Matsumoto, G., Inoshita, T., Yoshida, S., Ishihama, Y., Ryu, K.-Y., Nukina, N., Hattori, N., Imai, Y., 2014. Phosphorylation of mitochondrial polyubiquitin by PINK1 promotes parkin mitochondrial tethering. PLoS Genet. 10, e1004861. http://dx.doi.org/10.1371/journal.pgen.1004861

Shojaee, S., Sina, F., Banihosseini, S.S., Kazemi, M.H., Kalhor, R., Shahidi, G.-A., Fakhrai-Rad, H., Ronaghi, M., Elahi, E., 2008. Genome-wide linkage analysis of a Parkinsonianpyramidal syndrome pedigree by 500 K SNP arrays. Am. J. Hum. Genet. 82, 1375-1384. http://dx.doi.org/10.1016/j.ajhg.2008.05.005.

Shulman, J.M., De Jager, P.L., Feany, M.B., 2011. Parkinson's disease: genetics and pathogenesis. Annu. Rev. Pathol. 6, 193-222. http://dx.doi.org/10.1146/annurev-pathol011110-130242.

Singleton, A.B., Farrer, M., Johnson, J., Singleton, A., Hague, S., Kachergus, J., Hulihan, M., Peuralinna, T., Dutra, A., Nussbaum, R., Lincoln, S., Crawley, A., Hanson, M. Maraganore, D., Adler, C., Cookson, M.R., Muenter, M., Baptista, M., Miller, D., Blancato, J., Hardy, J., Gwinn-Hardy, K., 2003. alpha-Synuclein locus triplication causes Parkinson's disease. Science 302, 841. http://dx.doi.org/10.1126/science. 1090278.

Song, S., Jang, S., Park, J., Bang, S., Choi, S., Kwon, K.-Y., Zhuang, X., Kim, E., Chung, J., 2013. Characterization of PINK1 (PTEN-induced putative kinase 1) mutations associated with Parkinson disease in mammalian cells and Drosophila. J. Biol. Chem. 288, 5660-5672. http://dx.doi.org/10.1074/jbc.M112.430801.

Soper, J.H., Kehm, V., Burd, C.G., Bankaitis, V. a, Lee, V.M.-Y., 2011. Aggregation of $\alpha$-synuclein in $S$. cerevisiae is associated with defects in endosomal trafficking and phospholipid biosynthesis. J. Mol. Neurosci. 43, 391-405. http://dx.doi.org/10.1007/ s12031-010-9455-5.

Spillantini, M.G., Schmidt, M.L., Lee, V.M., Trojanowski, J.Q., Jakes, R., Goedert, M., 1997. Alpha-synuclein in Lewy bodies. Nature 388, 839-840. http://dx.doi.org/10.1038/ 42166.

Tain, L.S., Chowdhury, R.B., Tao, R.N., Plun-Favreau, H., Moisoi, N., Martins, L.M., Downward, J., Whitworth, a J., Tapon, N., 2009. Drosophila HtrA2 is dispensable for apoptosis but acts downstream of PINK1 independently from Parkin. Cell Death Differ. 16, 1118-1125. http://dx.doi.org/10.1038/cdd.2009.23.

Thao, D.T.P., An, P.N.T., Yamaguchi, M., LinhThuoc, T., 2012. Overexpression of ubiquitin carboxyl terminal hydrolase impairs multiple pathways during eye development in Drosophila melanogaster. Cell Tissue Res. 348, 453-463. http://dx.doi.org/10.1007/ s00441-012-1404-x.

Thomas, R.E., Andrews, L. a, Burman, J.L., Lin, W.-Y., Pallanck, L.J., 2014. PINK1-Parkin pathway activity is regulated by degradation of PINK1 in the mitochondrial matrix. PLoS Genet. 10, e1004279. http://dx.doi.org/10.1371/journal.pgen.1004279.

Todd, A.M., Staveley, B.E., 2008. Pink1 suppresses alpha-synuclein-induced phenotypes in a Drosophila model of Parkinson's disease. Genome 51, 1040-1046. http://dx.doi.org/ 10.1139/G08-085.

Tram, N.T.Q., Trang, N.T.T., Thao, D.T.P., Thuoc, T.L., 2013. Production of polyclonal antidUCH (Drosophila ubiquitin carboxyl-terminal hydrolase) antibodies. Monoclon. Antib. Immunodiagn. Immunother. 32, 105-112. http://dx.doi.org/10.1089/mab. 2012.0109.

Trempe, J.-F., Chen, C.X.-Q., Grenier, K., Camacho, E.M., Kozlov, G., McPherson, P.S., Gehring K. Fon, E. a, 2009. SH3 domains from a subset of BAR proteins define a Ubl-binding domain and implicate parkin in synaptic ubiquitination. Mol. Cel 36, 1034-1047. http://dx.doi.org/10.1016/j.molcel.2009.11.021

Trinh, K., Moore, K., Wes, P.D., Muchowski, P.J., Dey, J., Andrews, L., Pallanck, L.J., 2008. Induction of the phase II detoxification pathway suppresses neuron loss in Drosophila models of Parkinson's disease. J. Neurosci. 28, 465-472. http://dx.doi.org/10.1523/ JNEUROSCI. 4778-07.2008.

Tsai, P.-I, Course, M.M., Lovas, J.R, Hsieh, C--H Babic, M, Zinsmaier, KE, Wang X, 2014 PINK1-mediated phosphorylation of Miro inhibits synaptic growth and protects dopaminergic neurons in Drosophila. Sci. Rep. 4, 6962. http://dx.doi.org/10.1038/ srep06962.

Tufi, R., Gandhi, S., de Castro, I.P., Lehmann, S., Angelova, P.R., Dinsdale, D., Deas, E., Plun-Favreau, H., Nicotera, P., Abramov, A.Y., Willis, A.E., Mallucci, G.R., Loh, S.H.Y., Martins, L.M., 2014. Enhancing nucleotide metabolism protects against mitochondrial dysfunction and neurodegeneration in a PINK1 model of Parkinson's disease. Nat. Cell Biol. 16, 157-166. http://dx.doi.org/10.1038/ncb2901.

Ungewickell, E., Ungewickell, H., Holstein, S.E., Lindner, R., Prasad, K., Barouch, W., Martin, B., Greene, L.E., Eisenberg, E., 1995. Role of auxilin in uncoating clathrin-coated vesicles. Nature 378, 632-635. http://dx.doi.org/10.1038/378632a0.

Valente, E.M., Abou-Sleiman, P.M., Caputo, V., Muqit, M.M.K., Harvey, K., Gispert, S., Ali, Z., Del Turco, D., Bentivoglio, A.R., Healy, D.G., Albanese, A., Nussbaum, R., GonzálezMaldonado, R., Deller, T., Salvi, S., Cortelli, P., Gilks, W.P., Latchman, D.S., Harvey, R.J., Dallapiccola, B., Auburger, G., Wood, N.W., 2004. Hereditary early-onset Parkinson's 
disease caused by mutations in PINK1. Science 304, 1158-1160. http://dx.doi.org/10. 1126/science.1096284.

Van Epps, H.A., Hayashi, M., Lucast, L., Stearns, G.W., Hurley, J.B., De Camilli, P., Brockerhoff, S.E., 2004. The zebrafish nrc mutant reveals a role for the polyphosphoinositide phosphatase synaptojanin 1 in cone photoreceptor ribbon anchoring. J. Neurosci. 24, 8641-8650. http://dx.doi.org/10.1523/JNEUROSCI.2892-04.2004.

Vargas, K.J., Makani, S., Davis, T., Westphal, C.H., Castillo, P.E., Chandra, S.S., 2014 Synucleins regulate the kinetics of synaptic vesicle endocytosis. J. Neurosci. 34, 9364-9376. http://dx.doi.org/10.1523/JNEUROSCI. 4787-13.2014.

Venderova, K., Kabbach, G., Abdel-Messih, E., Zhang, Y., Parks, R.J., Imai, Y., Gehrke, S., Ngsee, J., Lavoie, M.J., Slack, R.S., Rao, Y., Zhang, Z., Lu, B., Haque, M.E., Park, D.S., 2009. Leucine-rich repeat kinase 2 interacts with Parkin, DJ-1 and PINK-1 in a Drosophila melanogaster model of Parkinson's disease. Hum. Mol. Genet. 18, 4390-4404. http:// dx.doi.org/10.1093/hmg/ddp394.

Venken, KJ.T., Kasprowicz, J., Kuenen, S., Yan, J., Hassan, B. a, Verstreken, P., 2008. Recombineering-mediated tagging of Drosophila genomic constructs for in vivo localization and acute protein inactivation. Nucleic Acids Res. 36, e114. http://dx. doi.org/10.1093/nar/gkn486.

Venken, K., Schulze, K., Haelterman, N., 2011. MiMIC: a highly versatile transposon insertion resource for engineering Drosophila melanogaster genes. Nature 8, 737-743.

Verstreken, P., Kjaerulff, O., Lloyd, T.E., Atkinson, R., Zhou, Y., Meinertzhagen, I. a, Bellen, H.J., 2002. Endophilin mutations block clathrin-mediated endocytosis but not neurotransmitter release. Cell 109, 101-112.

Verstreken, P., Koh, T.-W., Schulze, K.L., Zhai, R.G., Hiesinger, P.R., Zhou, Y., Mehta, S.Q., Cao, Y., Roos, J., Bellen, H.J., 2003. Synaptojanin is recruited by endophilin to promote synaptic vesicle uncoating. Neuron $40,733-748$.

Vilain, S., Esposito, G., Haddad, D., Schaap, O., Dobreva, M.P., Vos, M., Van Meensel, S., Morais, V. a, De Strooper, B., Verstreken, P., 2012. The yeast complex I equivalent NADH dehydrogenase rescues pink1 mutants. PLoS Genet. 8, e1002456. http://dx. doi.org/10.1371/journal.pgen.1002456.

Vilain, S., Vanhauwaert, R., Maes, I., Schoovaerts, N., Zhou, L., Soukup, S., da Cunha, R., Lauwers, E., Fiers, M., Verstreken, P., 2014. Fast and efficient Drosophila melanogaster gene knock-ins using MiMIC transposons. G3 (Bethesda) 4, 2381-2387. http://dx.doi. org/10.1534/g3.114.014803.

Vincow, E.S., Merrihew, G., Thomas, R.E., Shulman, N.J., Beyer, R.P., MacCoss, M.J., Pallanck, L.J., 2013. The PINK1-Parkin pathway promotes both mitophagy and selective respiratory chain turnover in vivo. Proc. Natl. Acad. Sci. U. S. A. 110, 6400-6405. http:// dx.doi.org/10.1073/pnas.1221132110.

Von Campenhausen, S., Bornschein, B., Wick, R., Bötzel, K., Sampaio, C., Poewe, W., Oertel, W., Siebert, U., Berger, K., Dodel, R., 2005. Prevalence and incidence of Parkinson's disease in Europe. Eur. Neuropsychopharmacol. 15, 473-490. http://dx.doi.org/10.1016/ j.euroneuro.2005.04.007.

Vos, M., Esposito, G., Edirisinghe, J.N., Vilain, S., Haddad, D.M., Slabbaert, J.R., Van Meensel, S., Schaap, O., De Strooper, B., Meganathan, R., Morais, V. a, Verstreken, P., 2012. Vitamin $\mathrm{K} 2$ is a mitochondrial electron carrier that rescues pink1 deficiency. Science 336, 1306-1310. http://dx.doi.org/10.1126/science.1218632.

Vos, M., Lovisa, B., Geens, A., Morais, V. a, Wagnières, G., van den Bergh, H., Ginggen, A., De Strooper, B., Tardy, Y., Verstreken, P., 2013. Near-infrared $808 \mathrm{~nm}$ light boosts complex IV-dependent respiration and rescues a Parkinson-related pink1 model. PLoS One 8 , e78562. http://dx.doi.org/10.1371/journal.pone.0078562.

Wang, D., Qian, L., Xiong, H., Liu, J., Neckameyer, W.S., Oldham, S., Xia, K., Wang, J., Bodmer, R., Zhang, Z., 2006. Antioxidants protect PINK1-dependent dopaminergic neurons in Drosophila. Proc. Natl. Acad. Sci. U. S. A. 103, 13520-13525. http://dx.doi. org/10.1073/pnas.0604661103.

Wang, C., Lu, R., Ouyang, X., Ho, M.W.L., Chia, W., Yu, F., Lim, K.-L., 2007. Drosophila overexpressing parkin R275W mutant exhibits dopaminergic neuron degeneration and mitochondrial abnormalities. J. Neurosci. 27, 8563-8570. http://dx.doi.org/10.1523/ JNEUROSCI. 0218-07.2007.

Wang, D., Tang, B., Zhao, G., Pan, Q., Xia, K., Bodmer, R., Zhang, Z., 2008. Dispensable role of Drosophila ortholog of LRRK2 kinase activity in survival of dopaminergic neurons. Mol. Neurodegener. 3, 3. http://dx.doi.org/10.1186/1750-1326-3-3.

Wang, X., Winter, D., Ashrafi, G., Schlehe, J., Wong, Y.L., Selkoe, D., Rice, S., Steen, J., LaVoie, M.J., Schwarz, T.L., 2011. PINK1 and Parkin target Miro for phosphorylation and degradation to arrest mitochondrial motility. Cell 147, 893-906. http://dx.doi.org/10. 1016/j.cell.2011.10.018.

Wang, H.-S., Toh, J., Ho, P., Tio, M., Zhao, Y., Tan, E.-K., 2014a. In vivo evidence of pathogenicity of VPS35 mutations in the Drosophila. Mol. Brain 7, 73. http://dx.doi.org/10. 1186/s13041-014-0073-y.

Wang, S., Tan, K.L., Agosto, M. a, Xiong, B., Yamamoto, S., Sandoval, H., Jaiswal, M., Bayat, V., Zhang, K., Charng, W.-L., David, G., Duraine, L., Venkatachalam, K., Wensel, T.G.,
Bellen, H.J., 2014b. The retromer complex is required for rhodopsin recycling and its loss leads to photoreceptor degeneration. PLoS Biol. 12, e1001847. http://dx.doi. org/10.1371/journal.pbio.1001847.

White, K.E., Humphrey, D.M., Hirth, F., 2010. The dopaminergic system in the aging brain of Drosophila. Front. Neurosci. 4, 205. http://dx.doi.org/10.3389/fnins.2010.00205.

Whitworth, A.J., Theodore, D. a, Greene, J.C., Benes, H., Wes, P.D., Pallanck, L.J., 2005. Increased glutathione S-transferase activity rescues dopaminergic neuron loss in a Drosophila model of Parkinson's disease. Proc. Natl. Acad. Sci. U. S. A. 102 8024-8029. http://dx.doi.org/10.1073/pnas.0501078102.

Whitworth, A.J., Lee, J.R., Ho, V.M.-W., Flick, R., Chowdhury, R., McQuibban, G.A., 2008 Rhomboid-7 and HtrA2/Omi act in a common pathway with the Parkinson's disease factors Pink1 and Parkin. Dis. Model. Mech. 1, 168-174. http://dx.doi.org/10.1242/ dmm.000109 discussion 173.

Wirdefeldt, K., Bogdanovic, N., 2001. Expression of $\alpha$-synuclein in the human brain: relation to Lewy body disease. Mol. brain 92, 58-65.

Wu, Z., Sawada, T., Shiba, K., Liu, S., Kanao, T., Takahashi, R., Hattori, N., Imai, Y., Lu, B. 2013. Tricornered/NDR kinase signaling mediates PINK1-directed mitochondrial quality control and tissue maintenance. Genes Dev. 27, 157-162. http://dx.doi.org/ 10.1101/gad.203406.112.

Yacobi-Sharon, K., Namdar, Y., Arama, E., 2013. Alternative germ cell death pathway in Drosophila involves HtrA2/Omi, lysosomes, and a caspase-9 counterpart. Dev. Cel 25, 29-42. http://dx.doi.org/10.1016/j.devcel.2013.02.002.

Yamamoto, A., Friedlein, A., Imai, Y., Takahashi, R., Kahle, P.J., Haass, C., 2005. Parkin phosphorylation and modulation of its E3 ubiquitin ligase activity. J. Biol. Chem. 280 3390-3399. http://dx.doi.org/10.1074/jbc.M407724200.

Yamamoto, H., Kakuta, S., Watanabe, T.M., Kitamura, A., Sekito, T., Kondo-Kakuta, C., Ichikawa, R., Kinjo, M., Ohsumi, Y., 2012. Atg9 vesicles are an important membrane source during early steps of autophagosome formation. J. Cell Biol. 198, 219-233. http://dx.doi.org/10.1083/jcb.201202061.

Yang, Y., Gehrke, S., Haque, M.E., Imai, Y., Kosek, J., Yang, L., Beal, M.F., Nishimura, I., Wakamatsu, K., Ito, S., Takahashi, R., Lu, B., 2005. Inactivation of Drosophila DJ-1 leads to impairments of oxidative stress response and phosphatidylinositol 3-kinase/Akt signaling. Proc. Natl. Acad. Sci. U. S. A. 102, 13670-13675. http://dx.doi.org/10.1073/ pnas.0504610102.

Yang, Y., Gehrke, S., Imai, Y., Huang, Z., Ouyang, Y., Wang, J.-W., Yang, L., Beal, M.F., Vogel, H., Lu, B., 2006. Mitochondrial pathology and muscle and dopaminergic neuron degeneration caused by inactivation of Drosophila Pink1 is rescued by Parkin. Proc. Natl. Acad. Sci. U. S. A. 103, 10793-10798. http://dx.doi.org/10. 1073/pnas.0602493103.

Yang, Y., Ouyang, Y., Yang, L., Beal, M.F., McQuibban, A., Vogel, H., Lu, B., 2008. Pink1 regulates mitochondrial dynamics through interaction with the fission/fusion machinery. Proc. Natl. Acad. Sci. U. S. A. 105, 7070-7075. http://dx.doi.org/10.1073/pnas.0711845105.

Yim, Y.-I., Sun, T., Wu, L.-G., Raimondi, A., De Camilli, P., Eisenberg, E., Greene, L.E., 2010. Endocytosis and clathrin-uncoating defects at synapses of auxilin knockout mice. Proc. Natl. Acad. Sci. U. S. A. 107, 4412-4417. http://dx.doi.org/10.1073/pnas 1000738107.

Yun, J., Cao, J.H., Dodson, M.W., Clark, I.E., Kapahi, P., Chowdhury, R.B., Guo, M., 2008. Lossof-function analysis suggests that $\mathrm{Omi} / \mathrm{HtrA} 2$ is not an essential component of the PINK1/PARKIN pathway in vivo. J. Neurosci. 28, 14500-14510. http://dx.doi.org/10. 1523/JNEUROSCI. 5141-08.2008.

Yun, H.J., Park, J., Ho, D.H., Kim, H., Kim, C.-H., Oh, H., Ga, I., Seo, H., Chang, S., Son, I., Seol W., 2013. LRRK2 phosphorylates Snapin and inhibits interaction of Snapin with SNAP-25. Exp. Mol. Med. 45, e36. http://dx.doi.org/10.1038/emm.2013.68.

Zapata, J.M., Martínez, M.A., Sierra, J.M., 1994. Purification and characterization of eukaryotic polypeptide chain initiation factor $4 \mathrm{~F}$ from Drosophila melanogaster embryos. J. Biol. Chem. 269, 18047-18052.

Zhang. B., Stewart, B., 2010. Electrophysiological recording from Drosophila larval body-wall muscles. Cold Spring Harb. Protoc. http://dx.doi.org/10.1101/pdb.prot5487 (pdb.prot5487-pdb.prot5487).

Zhang, L., Karsten, P., Hamm, S., Pogson, J.H., Müller-Rischart, a K., Exner, N., Haass, C. Whitworth, A.J., Winklhofer, K.F., Schulz, J.B., Voigt, A., 2013. TRAP1 rescues PINK1 loss-of-function phenotypes. Hum. Mol. Genet. 22, 2829-2841. http://dx.doi.org/10. 1093/hmg/ddt132.

Ziviani, E., Tao, R.N., Whitworth, A.J., 2010. Drosophila parkin requires PINK1 for mitochondrial translocation and ubiquitinates mitofusin. Proc. Natl. Acad. Sci. U. S. A. 107, 5018-5023. http://dx.doi.org/10.1073/pnas.0913485107. 